\title{
The abortion debate in American Christianity: church authority structures, denominational responses, and the stances of the affiliated
}

\section{Bryan Bohrer ${ }^{1}$ (D)}

Received: 25 January 2021 / Accepted: 21 January 2022 / Published online: 25 February 2022

(c) The Author(s) 2022

\begin{abstract}
With religion serving an important role in shaping individuals' stances on moral issues, the question of how religion impacts major social and political issues is of undeniable consequence. This paper explores both the response of Christian denominations in the USA to the evolving social dialog on abortion and the stances of affiliated members in relation to those denominational stances. For the first aspect, the organizational and authority structures of the denominations in question were examined to see if they play a role in how denominations responded to this social issue. For the second aspect, General Social Survey data were used to examine the general stances on abortion of the religiously affiliated belonging to specific polities over the past half-century. Polities were selected due to their similar organizational structures, as this granted insight into possible organizational influence at the individual level. This research highlights both the dissimilarities between similarly structured religious organizations and the general mindsets of the congregations on abortion as well as how the varying organizational structures in question exhibit inherent differences between one another yet have relative stability in their positions on abortion over time.
\end{abstract}

Keywords Abortion - Authority structures · Christianity · Denominations · Religious affiliation · USA

\section{Introduction}

Due to the nature of religion's importance when dealing with moral issues, the question of how religion is intertwined with politics is of irrepressible importance in the social sciences. In modern times, the role of religion in guiding political stances has

Bryan Bohrer

bryan.bohrer@gesis.org

1 Department of Knowledge Exchange and Outreach, GESIS-Leibniz Institute for the Social Sciences, Cologne, North Rhine-Westphalia, Germany 
been heavily researched from the perspective of clergy and evangelism (see Djupe and Calfano 2013; Djupe and Friesen 2018; Lewis and de Bernardo 2010). In the case of clergy, previous research has posited that they can be important political actors due to the "strategic positions they occupy in American religious and public life" (Smidt 2016, p. 2; see also Guth and Smidt 2019, p. 1) and their ability to both offer guidance on moral and public issues as well as mobilize their congregations (Djupe and Gilbert 2003). While clergy are overtly in the spotlight for their direct relationship with the denomination, one area of focus that requires a deeper look is that of the organizational structures of denominations and how churches as an organization have responded to social and political stimuli.

Furthermore, one area of study that requires more examination is the interplay between politics and religion. Michele Margolis (2018) studied this topic from the perspective of partisanship and religiosity, with evidence pointing toward partisanship in politics having an influence on the religious choices of parents (Margolis 2018). Moreover, Michael Hout and Claude Fischer (2002) discussed this with an eye toward the political activism of church leaders, arguing that this political character has pushed many Americans away from organized religion altogether. Whereas some authors have attempted to explain the relationships between society, religion, and politics, most have focused on how religion acts independently, changing the stances individuals hold on social issues (Gibson 2008; Sherkat et al. 2011; and Taylor and Merino 2011).

With this in mind, this study seeks to explore how various Christian denominations in the USA have responded to social issues that were pervasive through the social discourse. In most cases, these denominations are groups of congregations that are organized through the administration of a singular-legal hierarchy, making them ideal for examining their organizational structure and response.

Religious denominations have sought to address critical social issues throughout the history of the US. These issues ranged from "slavery to civil rights to today's advocacy in areas such as reducing poverty" (Lipka 2016), as well as to issues such as LGBTQ rights, environmental concerns, and capital punishment, just to name a few. In particular, one example of a critical social issue that has been pervasive in the American discourse has been the discussion on abortion rights, which has persisted as a topic in the US since the mid-twentieth century. This issue has led to conversation within and between the congregations and denominational leadership, which has forced many denominations to make declarations about the stance they would hold and to which they would attempt to adhere. These decisions required lengthy processes that, in some cases, overshadowed the religious discourse for the majority of the last half-century.

While such official stances of denominations have adopted new interpretation and focus over time, they serve as examples of how denominations function as organizations and how the popularizing of contested social issues leads to change within the denominations. Following within that vein of thought, this study serves to examine whether the organizational structure of the denominations in question correlates with how these decisions were made in the face of heated political debate. Following this examination, data collected by the General Social Survey (GSS) will be used to compare the mindsets of the respondents who are affiliated with the organizational 
structures in question and the trends present since the 1970s. Previous authors have also sought to examine how religious institutions' policies relate to the mindsets of the church members. In particular, David Masci complied a similar list of major religious groups' positions on abortion in 2016, with further data being included highlighting the views of religious group members on abortion from 2014 (Masci 2016; Pew Research Center 2014). Additionally, Hoffmann and Johnson (2005) examined attitudes of various religious traditions and found that Evangelicals' opposition to abortion, both for elective abortions and for abortions stemming from traumatic circumstances, has increased since the 1970s. This article will attempt to build on these past works by focusing on long-term trends from 1972 to 2018 while incorporating aspects of organizational theory to examine whether or not these policy decisions from the Christian denominations in question represent the laymen of their respective denomination. By examining the religious groups in such a way, insight into the possible (in)congruence of positions on abortion will allow for an investigation into how denominations have responded (if at all) and whether their positions represent their congregants' individual stances. With an understanding of how these religious entities then act, a better picture of how these actions, if at all, impact the overarching mindset of the congregations within the denominations can be surmised.

\section{Theory}

\section{Denominational organizational structure and religious authority}

The very nature of denominations requires structure to keep congregations in touch with one another and to uphold the importance of like-mindedness with regards to doctrine and proceedings, and as such, this means that denominations need an inherent organizational structure. Even with the concept of community at their core, they need a pseudo "informal contract" in the form of church membership or denominational affiliation to bring members together for the observance of regulations and for involvement in community events. Mark Chaves (1993) treated these as being part of dual structures: a structure of religious authority and a structure of agency; however, for the purposes of this study, focus is given to the structure of religious authority. The structure of religious authority is defined as "a social structure that attempts to enforce its order and reach its ends by controlling the access of individuals to some desired good" (1993, p. 149). Here, the concept of a "desired good" is meant as salvation, deliverance from sin or poverty, cure from illness, or even comradery. The religious entity holds these goods and grants access to them through adherence to regulations and expectations of how individuals carry themselves through daily actions.

With adherence being a staple of congregational expression, the inclusion of how denominations are organized regarding authority and clergy occupation is paramount. This study defines authority twofold. Firstly, formal authority is defined as the right to make decisions on the directions the greater denomination takes in reference to actions affecting a part or the whole of the organization. This is accompanied by real authority, which is effectively those that hold an 
effective control over decisions and those that make them (Aghion and Tirole 1997, pp. 1-2; see also Hanson and Xiang 2013).

Where this dichotomy becomes particularly interesting is within the different Christian denominations in the US, where authority is dispersed among clergy, the greater denomination (such as bishops or regional superintendents), and congregational members. In some instances, the clergy acts solely as a transmitter of the desires of the greater denomination. In other cases, the clergy makes decisions on the structure and proceedings of the congregation without control of the denomination playing a role. If, however, the denomination chooses to have an intermediary in communication, this relationship has either the clergy or some other representative of the congregation serving in the real authority role. Within all of these examples of authority structures, the relationships between the greater denomination and the congregations serve an integral role in explaining how much leverage is dispersed among the three main groups of the denomination's organizational design.

To that point, in order to understand how denominational stances have been produced, one is obliged to understand the structural makeup of the various denominations. One way of understanding this is through denominational authority structures. One common method of categorization used when exploring these structures is to split the denominations based on their hierarchical and authority structures into church polities. Within Christianity, four major polities exist: Episcopal, Presbyterian, Connexional, and Congregationalist. Each of these polities details the authority structure of the denominations and the level of autonomy local churches have on actions such as the hiring and firing of clergy, doctrine declarations, organizing volunteers, and resolutions regarding the churches' stances on specific issues. For the purposes of this study, denominations belonging to the Connexional polity are sorted into to the Presbyterian polity. This decision, as well as the denominations selected for examination, was based on the GSS data.

\section{Episcopal polity}

The first of these polities, the Episcopal polity, serves as a good illustration of Chaves's concept of religious authority in that it is a top-down hierarchical structure that functions with high levels of formal authority. Such formal structure has individual bishops that serve as regional leaders and representatives for that region. Often, these regional bishops are accountable to all bishops in higher statuses, such as those in the council of bishops. They are often chosen for their roles by the bishops and archbishops residing higher on the hierarchical structure and are in turn responsible for the local priests that reside within local churches and parishes. Typically, any actions taken that dictate the direction of the denomination as a whole will be made by the highest authority. The churches belonging to this polity are the Catholic Church, the Evangelical Lutheran Church in America, Lutheran Church-Missouri Synod, the Wisconsin Evangelical Lutheran Synod, and the Episcopal Church. 


\section{Presbyterian polity}

The Presbyterian polity has a similar hierarchical structure to the Episcopal polity. However, the local churches in these polities have more autonomy due to their ability to have a voice in choosing who their elders/representatives will be. For the Presbyterian polity, local elders are often elected by local congregations to represent them in any official meetings with local ministers. These local meetings, often known as the Presbytery, are made up of local collections of congregations. Presbyteries are then accountable to any higher board, often known as Synods, which serve as regional governing bodies made up of ministers and elders. These Synods in turn partake in some form of General Assembly - the governing body of the denomination and the highest authority - which holds the power to make doctrinal decisions on behalf of the denomination.

As was mentioned, some methods of categorization include a fourth polity: the Connexional polity. Here, the churches that belong to this polity follow very similar structures to the Presbyterian polity. However, the major differences that separate these polities come in the means by which local clergy is selected and the representation of the layperson in conferences. In the Connexional polity, local clergy are assigned to congregations by the bishops and have limited-term stays. This process, known as "itinerant ministers," is unique to Connexional churches. It is also unique in that it creates an authority dynamic where the local clergy is accountable to not only the bishop of the region, but also to the congregation in which they serve. Even with these differences, the churches belonging to the Connexional polity have been included in the Presbyterian polity in this work. This is done in part due to the overwhelming structural similarities between the churches of the two polities and in part due to the limited representation of the Connexional polity churches in the GSS data. The churches that are included in the Presbyterian polity in this work are the Presbyterian Church, USA; African Methodist Episcopal Church; and the United Methodist Church.

\section{Congregationalist polity}

The final form of polity presented here is the Congregationalist polity. Here, the hierarchy seen in the other polities is expressly removed, giving high levels of authority to the local church. Most denominations that adhere to this polity serve more as an association, bringing similar congregations from local churches together to create a network for ministry and extracurricular programs. Such associations rise out of similar doctrine, similar ministry, regional proximity, or even necessity due to lowering attendance numbers. Typically, these congregations are then responsible for their own ministry and their own doctrines. Where variance may exist is when the denomination-specific congregations meet for annual conferences and vote on any changes or resolutions that may be implemented. In such a scenario, the voters may be laypeople of a congregation or a representative. The churches belonging to this polity included in this work are the American Baptist Association; the American Baptist Church in the USA; the National Baptist Conventions of America; the National Baptist Convention, USA; and the Southern Baptist Convention. 


\section{Morals and controversial social issues}

With this understanding of how authority structures take form, the relationships of the clergy with both the congregation and the religious institution as a whole begin to take on new focus. This is all the more relevant when attention is given to the role of clergy and the religious institution when morals ${ }^{1}$ are considered. As Paul Djupe and Amanda Friesen discussed, clergy serve a crucial role within the context of their advancement of moral worldviews (2018, pp. 665-666). In particular, this is found when examining the moral foundations of clergy in the US, particularly in the face of moral disagreements with their congregations. In such cases, Djupe and Friesen found that clergy tend to emphasize individualizing foundations with their congregations and stress those morals that align with their religious beliefs. This is particularly relevant when considering that "those who emphasize religious authority devalue the individualizing foundations considerably" (ibid., p. 678). If clergy emphasize individualizing foundations when faced with moral disagreements, religious authority will lose importance when discussing how these morals are shaped. Other researchers have also emphasized how the institutions themselves guide moral considerations through binding (e.g., Graham and Haidt 2010). While both approaches are relevant to understanding morals, they focus on both institutions and clergy playing a role in guiding the morals of the congregants, meaning they inherently hold that their authority roles help shape existing moral foundations.

This of course is building off of the idea that views on discordant social issues are grounded in political affiliation and religious membership (Jelen 2009; see also Malka and Soto 2011; Malka et al. 2012). However, recent work by Paul Goren and Christopher Chapp has found evidence that "citizens habitually update their party loyalties, their beliefs about their preferred religious texts, and their religious commitments to better reflect their preferences on divisive culture war issues" (2017, p. 124). Therefore, it is crucial to examine how this may affect the decision-making processes of the denominations in question, as they would logically not wish to disenfranchise their members to the point of changing affiliation. Furthermore, some evidence has been found that fewer Americans feel that churches and religious groups are integral to solving social issues (Lipka 2016). If this is the case among those that are religiously affiliated, then the views they hold my not fall in line with that of the denominational stances of the religious group to which they adhere, which would fall more in line with the evidence found by Goren and Chapp (2017). If views on divisive social issues are instead in fact shaped by religious and political affiliation, evidence of denominational stances regarding abortion having an effect on the positions of the affiliated should be present.

While churches and denominations are much more than simply organizations of employed clergy and authority structures, they allow for a unique look into how organizational theory helps explain the movement of church doctrine in response

\footnotetext{
1 The concept of "morality" is one that has a number of meanings and interpretations. In the context of this paper, morality is defined as the discourse surrounding principles of ethical—or rather, of right and wrong-behavior.
} 
to societal stimuli regarding divisive social issues. With this in mind, the focus of this paper is twofold: Firstly, it focuses on the organizational structure of denominations in the US and how these structures operate in relation to authority and doctrine defining decisions. With a look into the history of the abortion debate in the US and a short outline of the denominational positional statements regarding abortion, how denominations have dealt with this issue can be better understood. While other authors have delved deeper into how specific groups have responded to this issue, e.g., see Lewis (2014) with the Southern Baptists; Williams (2011) with the GOP; and Williams (2015) with the Catholics and Evangelicals, such an in-depth analysis is beyond the scope of this paper. Instead, the relevant focus here is on what these statements actually say, how these statements work within the time periods they were enacted, and whether or not they represent those views of the affiliated. With an eye toward distinctive polities, a better understanding of how different organizational structures have handled the issue of abortion can be ascertained. Secondly, this paper focuses on the religiously affiliated through the usage of the GSS data and the general perception of abortion since the early 1970s. This approach allows for a unique look at how these denominations have responded and whether or not this corresponds to the general positions of those affiliated to specific polity structures.

\section{Historical context of abortion in the USA}

Many authors have written about the complex history of abortion in the US (e.g., Reed 1995; Williams 2011, 2015). For the purposes of this article, this brief discussion will cover the history of the abortion and birth control debates and religious activism in the US after WWII and will focus on the first major legislation regarding abortion to better prepare for a look into the denominational responses.

Following the Second World War, this issue of birth control dawned as new economic/social challenges for married couples arose. As families began to need a secondary income in order to hold specific statuses or classes, women began to enter into employment outside of the home. This of course meant that the traditional role of women in the household began to shift in relation to how much the mother worked and how much money was accessible to the family. Even while the majority of couples wanted large families $(5+$ children $)$, the reality was that most would have only two or three due to economic constraints (Reed 1995, p. 37). With this desire to limit the size of families to match any given financial situation, the topic of birth control became a highly controversial one with opposition being spearheaded both by those worried about economic growth being hampered by a declining birthrate and by religious groups that held firm to traditional family structures with large families. Of these religious groups, one of the most outspoken in support of strict anti-birth control laws was the Roman Catholic Church (Hofman 1986). The hierarchy of the Roman Catholic Church stood firmly opposed to all birth control methods and, in 1930, Pope Pius XI issued an official papal encyclical that officially banned any artificial methods of birth control (see Pope Pius XI 1930). This position would be softened heading into the 1950s and 1960s with both speculation focusing on the rising voices within the church that disagreed with full birth control regulation and 
also a desire to avoid controversy over issues of Catholic influence in shaping public policy in a time where the first Catholic presidential hopeful, John F. Kennedy, was running for president. However, the role of the Catholic Church in America still to this day is a force in opposition to abortion in the US, although this has shown evidence of diverging from the stances of US Catholic laymen in recent polling (Ben Hafsa 2015).

In the early 1950s, two distinct arguments regarding access to contraception arose. At a comprehensive level, it was a tool for controlling rapid population growth. At the individual level, the discourse shifted to a discussion of the traditional American family. Within such an individualistic argument, planned parenthood ideology flourished as it strove to reinforce the traditional roles of women as homemakers in the patriarchal hierarchy of traditional life, rather than push women's rights and feminist movements of the time. While this view obviously did not mesh with the growing voice of feminists seeking equality between women and men in the workforce and at home, it did help reinforce that family planning via birth control was no longer in opposition to the traditional role of women as housewives and caretakers. This served as a crucial tool for changing the dialog regarding birth control by allowing women to have fewer children without challenging the image of a woman as a housewife (Sharpless 1995, pp. 76-77).

Throughout the 1950s, this debate over birth control grew legs and was at full sprint going into the 1960s. During this time, new movements began to form to deal with the issue from both sides of the debate. In 1968, the Pro-Life Movement, now known as the National Right to Life Committee (NRLC), began with the goal of opposing all legislation that favored making contraception and abortion practices more easily accessible. One argument in the midst of this was that conception prevention was a means of population control, and in particular one that would target minority groups much more strongly than others. The Pro-Choice Movement, now known as the National Abortion Rights Action League (NARAL), began in 1969 with the conjoining of multiple smaller movements in order to support and pass legislation that made all safe forms of contraception and abortion legal and accessible. Their position, as the new movement for women's rights came to be a powerful force, posited that the right to abortion and contraception was a tool for protecting women's rights. Both of these movements together succeeded in making the rights of birth control and abortion front and center in the political dialog. Even today, both organizations still advocate their roles and are active in combating and pushing new legislature.

With the increasing polarization and saturation of the issue of birth control, the topic of abortion began to take on cultural and religious tones due to the struggle present in defining human nature. This was due to the fact that abortion "raises core philosophical questions about the nature of human life and human community [...] philosophically speaking, it symbolizes competing ideas of what constitutes meaningful life and death in our society, and in life what is the nature of human community" (Hunter and Davis 1995, p. 106). Ironically, with such unanswerable questions as when life truly begins, the nature of the abortion debate took on not only an emotional understanding, but a legalistic one as well, which is encapsulated in the current statements of the two aforementioned movements: 
- "The mission of National Right to Life is to protect and defend the most fundamental right of humankind, the right to life of every innocent human being from the beginning of life to natural death" (NRLC Mission Statement 2021).

- "The right to choose abortion is essential to ensuring a woman can decide for herself if, when and with whom to start or grow a family. We'll never stop fighting to protect and expand this fundamental human right" (NARAL Issues: Abortion Access 2021).

For the NRLC, the focus is on the rights of the fetus. If one holds the belief that life begins at conception, or shortly thereafter, the argument is tied both to an understanding of life and the governmental rights granted thereto. For the NARAL, the argument focuses instead on the rights of the woman, clearly denoting that the right to choose is the penultimate right that needs protecting. With the focus being on defining life, death, and the protection of rights, one can quickly see why this issue has become one of the most pervasive and persistent social issues of the twenty-first century in the US.

During this time, individual denominations had internal discussions among the congregants and leaders regarding the abortion debate; this was furthered by larger movements going beyond the boundaries of denomination. As Williams (2015, p. 465) explains, the 1970s brought about a swing in the Evangelical discussion of anti-abortion that shifted the argument away from the Catholic perspective of "the liberal social welfare state," which had been pushing for social welfare reform and protective rights, and instead focused on the fight against "a malevolent secular state." As Williams writes, Francis Schaeffer, a well-known Presbyterian missionary and bestselling Christian apologist, succeeded in giving evangelicals a platform to campaign against abortion in a uniquely Protestant way:

By portraying the campaign against abortion as a fight against the tyranny of a secular state, Schaeffer reframed what had been a Catholic human rights cause grounded in New Deal liberalism and transformed it into the centerpiece of a conservative evangelical fight for the restoration of Christian-based law in the nation and curbs on the power of the secular judiciary. [...] At a time when many conservative evangelicals were becoming increasingly alarmed about the sexual permissiveness and changes in gender roles in American society, and at a time when many feared that the state had rejected Christian values, the use of Roe as a symbol for the evils of a secular state made sense. (ibid., p. 465)

Following in the vein of argumentation of Schaeffer's call to action-which occurred in the late 1970s and early 1980s-other well-known Evangelicals such as Pat Roberson, Jerry Falwell, and James Dobson began taking up the mantle of fighting for anti-abortion laws and putting opposition to abortion at the center of their moral views. In particular, televangelist Jerry Falwell began sensationalizing the issue, pushing scare tactics to mobilize a base against abortion activism (McKeegan 1993). In his autobiography, he stated that "Satan has mobilized his own forces to destroy America by negating the Judeo-Christian ethic, secularizing our society, and devaluing human life through the legalization of abortion and infanticide" (Falwell 1987, 362). 
These calls to action and narrative evoking a moral fight contributed in part to a number of denominations passing pro-life resolutions (in particular, the Southern Baptist Convention and the Presbyterian Church in America). With such a shift in mindset, particularly among Evangelicals, advocacy against abortion took on a different feel from the Catholic past. The new anti-abortion argument was one of morality, taking on the purpose not of defending the rights of women or the rights of the unborn, though these rights were not removed from the discourse, but rather the purpose became the defense of religion, the defense of morals, and the simple goal of changing the nation's laws (Williams 2015, pp. 465-466).

In 1973, the first of many rapid changes in the discourse surrounding abortion came when the Supreme Court voted in the legal case Roe v. Wade in favor of constitutionally protecting the right to abortion. While this served as a landmark casein that it shifted abortion laws across the entire US in favor of abortion-it also sparked a surge of states responding to the new reality. As James Reed comments, "Within 6 months of the Roe v. Wade decision, 188 anti-abortion bills were introduced in 41 states" (1995, p. 46). While the right to abortion was now protected by law, lawmakers at the state level still fought over how accessible such rights should be. Even though the discussion initially was avoided by politicians at the state level, the ruling of Roe became so contested and was so salient in the political discourse that it inevitably became entangled in partisan politics. As Ian Mylchreest notes, "After 1973 Roe v. Wade provided the most visible target for opponents of reform. By the 1980s, the Republican Party was committed to reversing the decision; Democrats responded by promising to defend, judicially and legislatively, a woman's right to choose" (1995, p. 61). Roe had made the issue of abortion rights mainstream, meaning it was front and center on the ballot for many politicians.

Since then, a number of legislative moves were taken on the federal level that covered numerous aspects of abortion rights and abortion access. Where this led for the denominations in question, however, was a raucous debate over opposition and support of abortion and the fine details surrounding this complex topic that has so far lasted well into the twenty-first century.

\section{Denominational responses to the topic of abortion}

Various Christian denominations that began discussing abortion were forced to struggle with the nuance of the topic. For instance, a clear divide between abortions as a means of birth control, also known as elective abortions, and abortions following a traumatic experience began to surface. In the current work, reasons for abortions that have been considered "elective" by previous scholars are termed lifestylebased (LS) and reasons for abortions due to traumatic experiences or health-based concerns have been termed health-and-wellbeing (HWB). For ease of understanding, LS based reasons for abortion include women seeking abortions because their family cannot afford more children, women seeking abortion because they are not married and do not want more children, and women seeking abortion because they are married and do not want any more children. HWB reasons for abortion include women seeking an abortion because of a strong chance of defect in the baby, women 
seeking abortion because her health is seriously endangered, and women seeking abortions when the pregnancy was the result of rape. ${ }^{2}$ For the former, strong opposition was found among the Christian denominations, with only a handful crafting positional statements that stated support for LS abortions. Hoffmann and Johnson (2005) found this to be true across various religious traditions; however, Evangelicals in particular were found to have increasing opposition to HWB abortions as well. This trend of opposition to HWB abortions was not as widespread, with a number of Christian denominations either supporting or somewhat supporting them. In order to better understand the milieus out of which these mindsets have surfaced, a deeper examination of the individual Christian denominations and their responses to the issue of abortion is necessary. As such, this section delves into the individual denominations in an effort to detail the historical relationship between these groups and their positional statements on abortion.

\section{Denominations belonging to the episcopal polity}

\section{Roman Catholic Church (RCC)}

The RCC, while being active in opposing legislation that stands to make abortion more easily accessible, has actively denounced pro-abortion legislation since the onset of the twentieth century. One year after Roe, the Vatican released the Declaration on Procured Abortion (1974), which bolstered the right to life as the first and most fundamental right of all humans. This declaration stated that the right to life is one that does not belong to authority or society, and that all actions taken against this right are "evil" (See Congregation for the Doctrine of the Faith 1987).

Interestingly, the initial anti-abortion movement was actually one advocated by a more liberal voice. As Williams writes, "pro-life advocates argued that the fetus was a powerless minority [...] Catholic lawyers of the 1960s and 1970s claimed that the Fourteenth Amendment protected the unborn," and "like civil rights advocates, prolife activists believed that their campaign was an effort to protect the powerless-in this case, the fetus-against the powerful" (2015, p. 456). This movement was an attempt by the Church to prevent what was perceived as "infanticide" and to protect minority groups, since many believed that legalized abortion would likely disproportionately affect the black population (ibid., p. 455).

Pope John Paul II also made numerous statements urging politicians to take action against abortion and labeled any legislation supporting abortion as "a most serious wound inflicted on a society and its culture by the very people who ought to be society's promoters and defenders" (Pope John Paul II 1995), while Pope Francis has even claimed that abortion is the equivalent to hiring a hitman. ${ }^{3}$ This view is extended to birth control as well, with Pope Paul VI and Pope John Paul II claiming that contraceptives act against the very nature of procreation, which is understood as

\footnotetext{
2 These reasons make up the six questions asked to respondents in the GSS about which situations they felt abortion was acceptable. This will be discussed further in the Data and methods section.

3 Horowitz (2019).
} 
serving as an extension of promiscuity and hedonism (see Pope Paul VI 1968; Pope John Paul II 1995).

\section{Evangelical Lutheran Church in America (ELCA)}

The ELCA has made one major statement regarding birth control and abortion. A social statement was issued at the Churchwide Assembly in 1991 that sought to move the discussion away from the topics of "rights" and to bridge the divide between the sides. The statement acknowledges the major divisions that abortion had created in society and within the church. As such, the statement asserts "the concern for both the life of the woman and the developing life in her womb expresses a common commitment to life. This requires that we move beyond the usual 'pro-life' versus 'pro-choice' language in discussing abortion" (1991, p. 2). Furthermore, the social statement clearly defines that abortion should be available in situations of health-based and wellbeing concerns. However, they support legislation that restricts late-term abortions, except in situations of health concerns for either the mother or the child (ibid., p. 10).

\section{Lutheran Church-Missouri Synod (LCMS)}

Since 1971, the LCMS has held firm beliefs against abortion. In a report issued in 1984, the LCMS details their medical, legal, and theological reasons for opposing abortion. Within this report, the commission pushes for constant action in support of pro-life movements through the understanding of morality, theology, and the rights of the unborn. Furthermore, the report urges adherents to continue to fight any legislation that legalized abortion (Social Concerns Committee 1984).

\section{Wisconsin Evangelical Lutheran Synod (WELS)}

The WELS issued their first statement against abortion in 1971, which spoke against abortion and sought for members to support abortion-alternative programs. In 2011, a resolution was passed that called again for action against abortion. This resolution addressed the topic of health-based reasons for abortion, stating "in those extremely rare circumstances in which a pregnancy directly endangers the physical life of the mother, or the mother's condition directly endangers the life of her unborn child, we call for action toward preserving both lives, however, possible or preserving at least one life when preserving both lives is not possible" (WELS 2011).

\section{Episcopal Church}

In 1967, the Episcopal Church stated its support for health-based reasons for abortion and general support for responsible birth control practices in wedlock, reaffirming this statement in 1976. In 1982, the 67th General Convention clarified that they condemned abortion for the purpose of sex selection and non-serious abnormalities of the fetus. The issue of abortion surfaced two more times in the 1980s, with a resolution in 1985 to initiate studies into abortion and, in 1988, with two resolutions 
stressing the sacredness of human life and condemning violence against abortion clinics. In 1991, one year before Planned Parenthood v. Casey, ${ }^{4}$ the 70 th General Convention voted to reject opposing governmental action that limits a woman's decision and voted to oppose any legislation that requires parental consent for minors seeking abortions. After Planned Parenthood v. Casey, many states began adopting laws that, in essence, limited access to information and abortions for women. In response, the 71st General Convention reaffirmed their stance on the sacredness of human life when dealing with abortion, but also expressed opposition to any governmental restrictions on related information and access to abortions. This was further extended in 1997 with a resolution that expressed "grave concern" over nonextreme uses of partial-birth abortions and requested studies be performed looking into "beginning of life issues." Finally, the 73rd General Convention passed a resolution to support those suffering from post-abortion stress and to make parishes safe havens for those seeking pastoral care (The Acts of Convention 1976-2000).

\section{Denominations belonging to the Presbyterian polity}

\section{Presbyterian Church, USA (PCUSA)}

The 182nd General Assembly (1970) released the PCUSA's first statement on abortion declaring it as an ethical decision for the women to make, meaning it should not be limited by law. While it would not be until 1992 that the next statement would be made, the decades between the first and second statement were filled with debate about the denominational position. In the 204th General Assembly in 1992 (see Presbyterian Church USA 2022), the stance taken regarding abortion reaffirmed the right of the woman to make this decision, but stressed that abortions should not be used as a method of birth control and that abortion is not morally acceptable for gender selection only or solely to obtain fetal parts for transplantation. While the complexity of the issue was acknowledged, the statement did support recognizing health-based reasons for abortion as justifiable (see Presbyterian Mission 2016).

With the upsurge in discussions regarding late-term pregnancies beginning in the 1990s, the 217th General Assembly in 2006 (see Presbyterian Church USA 2022) released a statement where they declared opposition to late-term abortions and sought to create a support system within the church for any mother dealing with a "problem pregnancy."

\footnotetext{
4 Planned Parenthood v. Casey was in essence a reaffirmation of Roe v. Wade, but the majority of Pennsylvania law provisions that had instigated the case being brought to the Supreme Court (e.g., 24 h waiting period prior to procedure and informed consent) were upheld. The requirement of husband notification was stricken down due to the "undue burden" caused on the woman's path to seeking an abortion. States were constitutionally granted the ability to regulate abortion as long as it did not post an "undue burden" on those seeking abortion (see "Planned Parenthood of Southeastern Pennsylvania v. Casey" 1992).
} 


\section{African Methodist Episcopal Church (AME)}

The AME has strongly opposed abortion since 1976, with the General Conference's working papers detailing strong opposition to abortion while including both room for the forgiveness of those that had undergone an abortion and education to prevent unwanted pregnancies. Four years later, the General Conference would once more be presented with another statement that recognized the necessity for abortion as a life-saving measure for the mother (see Shelton 1997).

\section{United Methodist Church (UMC)}

The UMC's history with abortion has been ever changing. In the first official statement of the UMC, the 1972 General Conference adopted a statement that supported the removal of abortion from the criminal code, placing it instead under laws relating to other procedures of standard medical practice. This statement was almost immediately met with opposition within the denomination. Four years later in 1976 and in almost every General Conference thereafter, there have been revisions to the positional statement of the denomination with the majority of these amendments being toward stricter guidelines as to the moral acceptability and nature of abortion (see Stallworth 2008). As of 2016, the official statement of the UMC still holds that abortion, while the choice of the women should not be a means of birth control and is justified under conflicts of "life with life" (see The Book of Discipline of The United Methodist Church 2016).

\section{Denominations belonging to the Presbyterian polity}

\section{American Baptist Association (ABA)}

The ABA has made no official statement regarding their stance on abortion.

\section{American Baptist Church in the USA (ABC)}

The General Board of the ABC posted a resolution in 2002 to the official church website that opposed abortion as a means of birth control and as an effort to avoid responsibility for conception. While not directly condemning abortion, the statement discouraged the practice and encouraged women and men to seek spiritual council before making any decision (General Board of American Baptist Churches in the USA 2002). 


\section{National Baptist Convention of America (NBCA)}

The NBCA has made no official statement regarding their stance on abortion.

\section{National Baptist Convention, USA (NBC)}

The NBC has made no official statement regarding their stance on abortion.

\section{Southern Baptist Convention (SBC)}

Although the SBC lacked consensus on the issue in the 1970s, a 1971 resolution called for legislation that would allow for abortion under such conditions as rape, incest, severe fetal deformity, and when the mother was in danger (Lewis 2014, p. 528; see also Resolution on Abortion 1971). Since then, there was a shift in the denomination toward a more pro-life agenda through the campaigning of pro-life pastors, with the Resolution on Abortion (1980) declaring the SBC's opposition to most forms of abortion, save those protecting the wellbeing of the mother. The majority of these resolutions have opposed all three issues, with resolutions calling for members to take action in supporting legal action against them (On The Sanctity Of Human Life 2015).

\section{Polities in context}

Even when denominations exhibited similar organizational structures, there was a high level of diversity in the stances taken regarding abortion. This was evident even within some denominations, with stances shifting over time from either a neutral stance outward, or vice versa. It could have also been assumed that the Congregationalist polity, being without high levels of authority, would have had the greatest level of diversity among denominations. However, evidence points rather to the conscious decision by the majority of denominations (save the $\mathrm{ABC}$ and the SBC) to not make an official statement on abortion. For reference, Table 1 covers how the denominations are sorted into polities and their general stance on abortion over the timespan.

While the focus thus far has been at a macro-level regarding the positional statements of various denominations, seeing how this relates to the actual beliefs of the members of the congregations is paramount to understanding how the religious authorities interact, if at all, with the beliefs and convictions of the members. For this reason, further analysis will be carried out with the use of the GSS to better understand the beliefs held by the affiliated members.

\section{Data and methods}

For this study, GSS data from 1972 to 2018 were used (see Smith et al. 2019). The GSS is a repeated cross-sectional survey that, since 1994, was performed every two years. The survey from 1986 did not include questions on abortion and is thusly not included. 


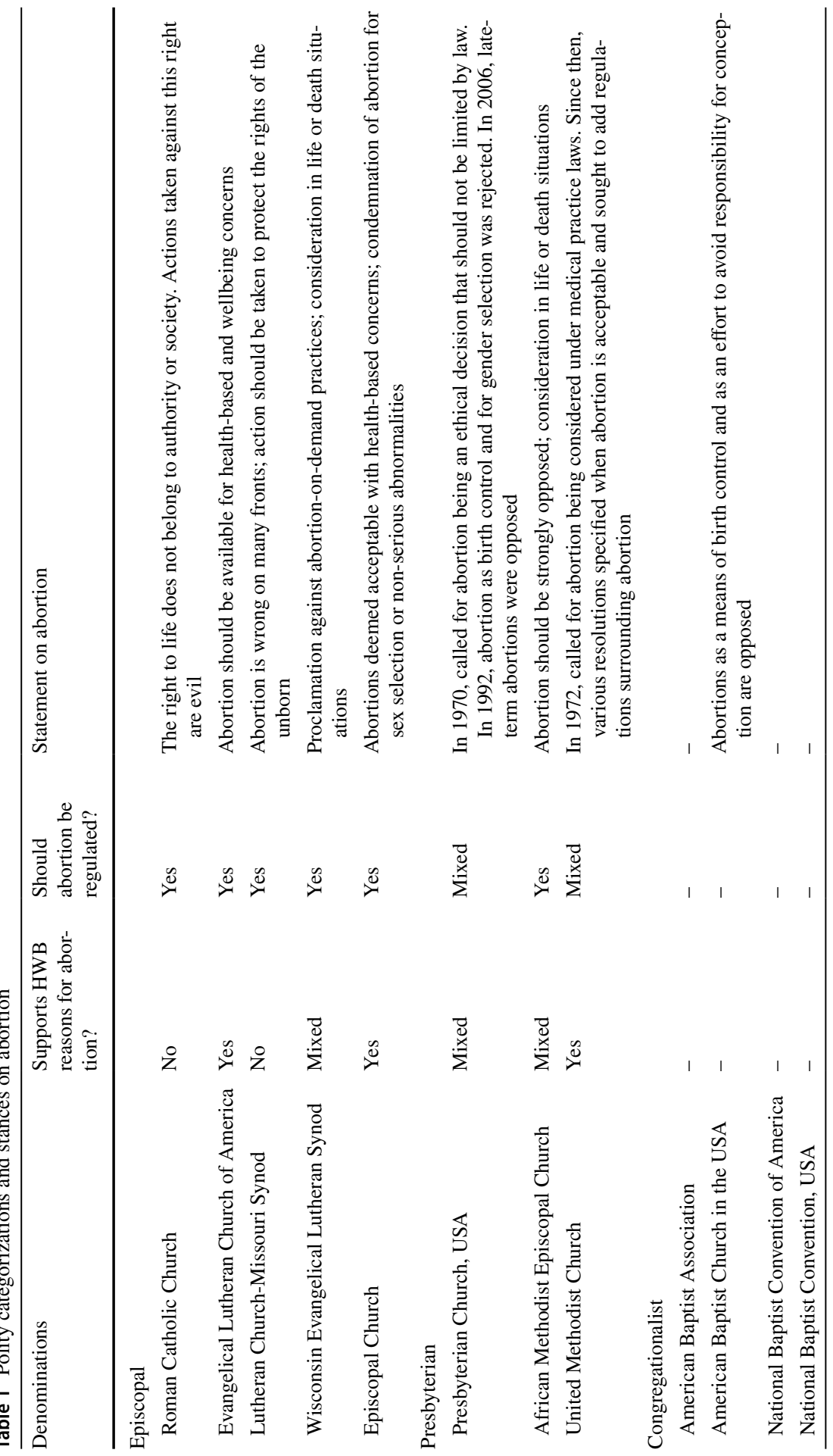

SN Social Sciences

A SPRINGER NATURE journal 


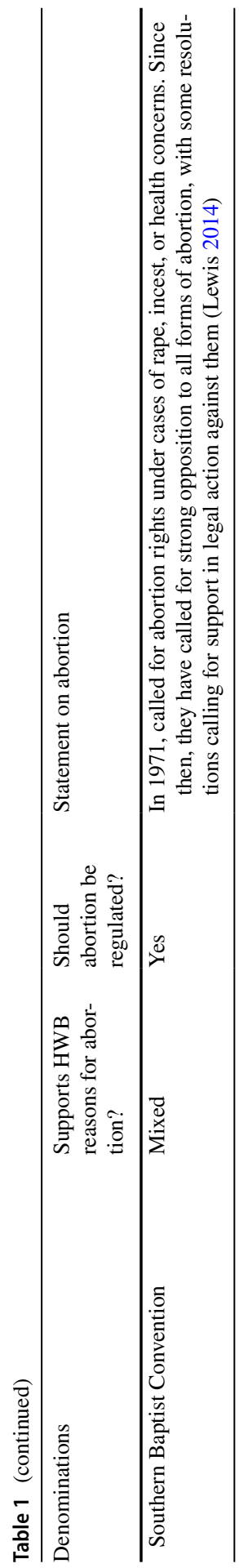


For the topic of abortion, respondents were asked six questions regarding which situations abortion was deemed to be acceptable. Each question referenced different situations where abortion might be considered, including if there is a strong chance of serious defect in the baby, if the woman's own health is seriously endangered, if the pregnancy was the result of rape, if the family cannot afford any more children, if the woman is married and does not want any more children, and if the woman is not married and does not want to marry the man. These questions were setup in a yes or no format. Firstly, the questions regarding the health of the woman, health of the baby, and situations regarding rape were combined to create an index for healthand-wellbeing-based reasons for abortion (HWB). The remaining questions regarding whether or not the family could afford more children, whether the woman was married and did not want any more children, and whether the woman was not married and did not want any more children have been combined to create an index for lifestyle-based reasons for abortion (LS). ${ }^{5}$ For the polity categorization, Protestant denominations were divided into the three polities discussed earlier: Episcopal, Presbyterian, and Congregationalist. Prior to 1984, the GSS categorized Protestant denominations only by the major denominational branches (e.g., Methodist, Baptist, etc.).

For control variables, age, sex, education, religious service attendance, political party affiliation, region, and strength of religious affiliation were used. The two religious variables regarding attendance and strength of religious affiliation were included to test the strength of respondents' religiosity and how it impacts their stances on abortion. For ease of interpretation, strength of religious affiliation was inversely coded to $1=$ somewhat strong affiliation and $3=$ strong affiliation ("no affiliation" was not included as this was not selected by respondents with a religious affiliation). Religious attendance was coded on a scale of eight, with $0=$ never and $8=$ more than once a week. The variable on political affiliation was coded on a scale of seven, with $1=$ Strong Democratic, $4=$ Independent, and $7=$ Strong Republican. The region variable denotes where in the US the interview was held, with the original nine item variable being recoded to Northeast, Midwest, South, and West. This variable serves to address whether there exist geographical social factors that impact stances on abortion. Furthermore, a variable regarding respondents' confidence in the people running organized religion was included to test if this confidence has either an impact on the effect of religious variables or on abortion stances. The confidence variable was coded $1=$ hardly any confidence to $3=$ a great deal of confidence. The effects of specific decades were also included. As such, all five decades since 1970 are included. Regressions were done using pooled ordinary least squares (OLS) with robust standard errors. OLS regressions are ideal when analysis is being performed to estimate the parameters in a linear equation. The results of an OLS regression can be used to predict how a single variable's value can change based on other variables. In this context, OLS regressions make sense due to the linear

\footnotetext{
${ }^{5}$ Hoffmann and Johnson (2005) used a similar means of categorization when using the GSS data and found that these six variables for abortion create two distinct latent variables for elective (LS) and traumatic (HWB) abortions along the lines of how they are categorized in this work.
} 
Table 2 Observations per decade by polity

\begin{tabular}{lcccc}
\hline Decade & Episcopal & Presbyterian & Congregationalist & Total \\
\hline $1972-1978$ & 3838 & 1833 & 2210 & 7600 \\
$1980-1989$ & 4264 & 1882 & 2843 & 8679 \\
$1990-1998$ & 4414 & 1758 & 2660 & 8527 \\
$2000-2008$ & 4545 & 1493 & 2648 & 8396 \\
$2010-2018$ & 3299 & 899 & 1812 & 6010 \\
Total & 20360 & 7865 & 12173 & 40398 \\
\hline
\end{tabular}

Source GSS 1972-2018

relationships between the dependent and independent variables, as will be discussed in the next section. Additionally, the usage of robust standard errors helps to deal with the unknown structure of heteroskedasticity common in large samples.

\section{Initial findings}

In total, 40,398 observations belonging to one of the polity groups are present. Table 2 displays the total number of observations for each polity. While not the focus of this study, the decrease in respondents in the most recent decade touches on the current debate of whether the US is still a counterexample to the secularization thesis (see Voas and Chaves 2016). Within this context, it is worthwhile to briefly touch on the process of secularization as it is present in other areas of the world. Secularization is, briefly explained, a term describing the phenomenon of people becoming less and less religious within societies. As Pollack (2015) writes, secularization can be described via the claim that "the social significance of religion in modern societies is weakening in comparison to earlier epochs [and that] the decline in the importance of religion can be attributed to processes of modernization" (2015, p. 64). Numerous scholars have found evidence corroborating this claim in the US (Bruce 2011; Newport 2015; Norris and Inglehart 2004) and in Europe (e.g., Bruce 2002, 2011; Mueller 2009; Pollack 2009, 2015). However, there have been some scholars contesting this, claiming that religiosity itself is not decreasing, but instead that modernization has simply led to a weakening of the role of religious institutions, but not individualistic belief (e.g., Davie 1990, 1996). Other authors have also disputed secularization claims by using a more economic mindset, claiming that religion, particularly in the US, operates under a "religious market model." Here, laymen are understood to be religious consumers, while churches and religious institutions are seen as producers (Iannaccone 2012, p. 111; see also Finke and Stark 2005; Iannaccone et al. 1997). Proponents of this model hold that "open competition benefits religious markets much as it does secular markets, pushing churches and clergy to efficiently produce a wide range of alternative faiths well adapted to the needs of their members" (Iannaccone 2012, p. 111). Even while some evidence has shown that these claims have some merit, it does not take away from the clear trend of increasing levels of individuals in the US no longer affiliating with any religion, 
with this number having steadily increased in the twenty-first century to more than a fifth of Americans being found to have no religious identity in 2017 (Newport 2015, 2017; see also Cox and Jones 2017; Voas and Chaves 2016). For many of these individuals, this includes decreasing importance placed on religion and a disaffiliation with religious groups and religious practice altogether (Hoge et al. 1993; Uecker et al. 2007). Within the context of this work, this is most apparent within the Presbyterian polity, with substantial decreases in adherents in twenty-first century.

In order to test whether the variables in question are correlated with our dependent variables (HWB and LS indexes), a Pearson's correlation was run with the results being displayed in Table 3. For ease of understanding, these correlations represent the magnitude of the correlation between two variables and the direction. Additionally, these values only fall between 1 (perfect positive correlation) and -1 (perfect negative correlation). At first glance, every variable has a highly significant correlation with the two abortion indexes, albeit with varying levels of strength. However, the focus given to confidence in organized religion requires a further examination using partial correlations to see how it correlates to the abortion indexes when religious and political affiliations are held constant. This is done in order to test not only which affiliation is integral to understanding stances on the abortion issue, but also whether confidence in religious organizations plays a significant role. These correlations can be seen in Table 4.

When religious and political affiliations are held constant, confidence in organized religion does not significantly correlate with the HWB index. Furthermore, the strength of the correlation between political party affiliation and the HWB index becomes substantially stronger, while the religious affiliation weakens. This could be interpreted as political party affiliation playing a much more important role for individuals when stances on health-and-wellbeing reasons for abortions are considered. Religious affiliation still correlated weakly with the index, meaning political party affiliation is not the only deciding correlation. As for the LS index, the roles of religious and political party affiliation reversed, with religious affiliation becoming much stronger with the other variables controlled for and the strength of the correlation between political party affiliation and the LS index becoming much weaker. Confidence in organized religion was also highly significant and weakly correlated with lower support for LS abortions. Here, it appears that the religious affiliation of individuals and the confidence they have in organized religion play a stronger role in shaping LS abortion stances than political party affiliation.

Finally, a separate Chi-square test of independence is necessary to see how region and the abortion indexes are related. This separate test is necessary because the variable for region is nominal; results can be seen in Table 5. Here, both the information regarding how the respondents from each region answered the various questions on abortion as well as the chi-square statistic were included. In both cases, there is statistical evidence that there is a significant association between region and the abortion indexes. Furthermore, interesting trends can be gathered through the examination of the results. When looking at the HWB results, all regions showed majority support for the HWB reasons for abortions; however, the South was the lowest with $69.7 \%$ support. For the cases where there were mixed responses (i.e., respondents had both "yes" and "no" answers to the questions about HWB reasons 


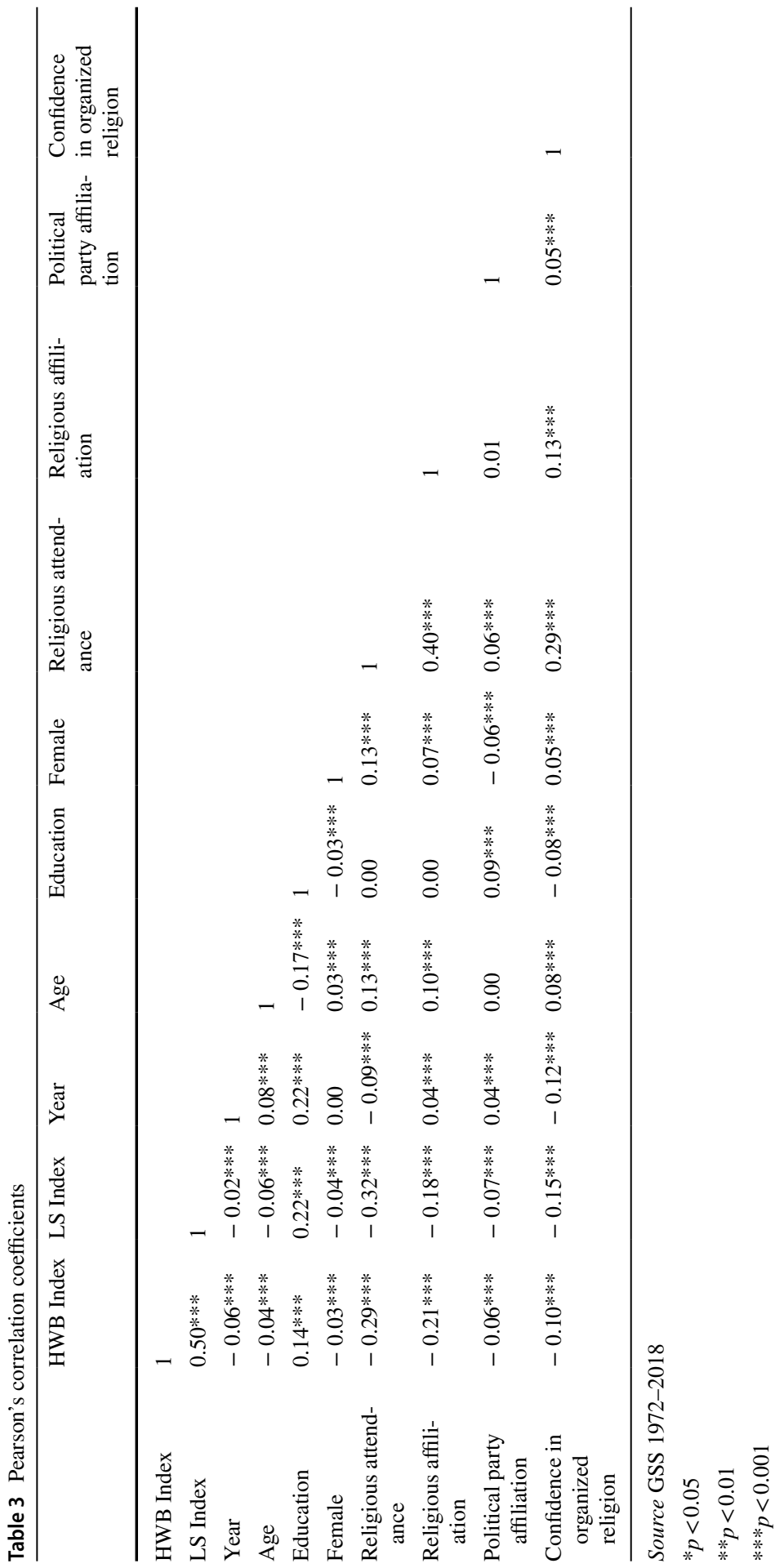


Table 4 Partial correlations for confidence in organized religion and affiliation variables by abortion indexes

\begin{tabular}{llllll}
\hline & HWB Index & & LS Index \\
\cline { 2 - 3 } \cline { 5 - 6 } & Partial correlation $(r)$ & $\begin{array}{l}\text { Sig- } \\
\text { nificance } \\
\text { value }(p)\end{array}$ & $\begin{array}{l}\text { Partial correlation }(r) \\
\text { Relig- }\end{array}$ & $\begin{array}{l}\text { Sig- } \\
\text { nificance } \\
\text { value }(p)\end{array}$ \\
\hline Confidence in organized religion & -0.00 & 0.886 & $-0.09 * * *$ & 0.000 \\
Political party affiliation & $-0.10^{* * *}$ & 0.000 & & $-0.17 * * *$ & 0.000 \\
\hline
\end{tabular}

Source GSS 1972-2018

$* p<0.05$

$* * p<0.01$

$* * * p<0.001$

for abortions), the spread across all regions was relatively similar, with within differences falling within 5-6\% points of each other. For the LS index, a different trend of polarization was observed. Here, the Northeast and the West regions showed slightly higher levels of respondents with full support of abortions than the South and Midwest regions; however, this was not a majority. In the Midwest and South, the majority of respondents showed no support for any of the reasons laid out in the LS index. In all regions, the responses favored heavily either full or no support, with only somewhere between 13 and $17 \%$ of respondents mixing their responses.

Table 6 includes the descriptive statistics for the control variables. For all three polities, the average age of respondents has increased steadily since the 1970s. For the Presbyterian polity, this effect is much more pronounced with the initial age being higher than that of the other polities and increasing at an accelerated rate. This slow effect of an aging denomination explains the slow increase in education. This is supplemented by a national rising average in years of education and tertiary enrollment since the 1970s (Davis and Bauman 2013). The averages for religious attendance seem to highlight diverging trends, with the Episcopal polity showing lowering attendance rates, the Presbyterians showing increasing rates, and the Congregationalists showing relative stability over the decades.

Strength of affiliation appears to be stable and similar for all polity groups, while political party affiliation shows the Presbyterian polity being slightly more Republican leaning than the other polities and the Congregationalists showing signs of becoming less Democratically leaning over the decades. As for confidence in organized religion, the averages were quite stable and similar for all groups, with a slight leaning toward "some confidence" (2). The percentage of women belonging to each polity throughout the decades is also of note because women were always the majority.

Figure 1 examines the percentage of each polity affiliation according to region and decade. It is important to note before examining this figure that this is only those individuals that were affiliated to one of the Christian denominations in question, meaning this does not include any religious affiliations outside of 


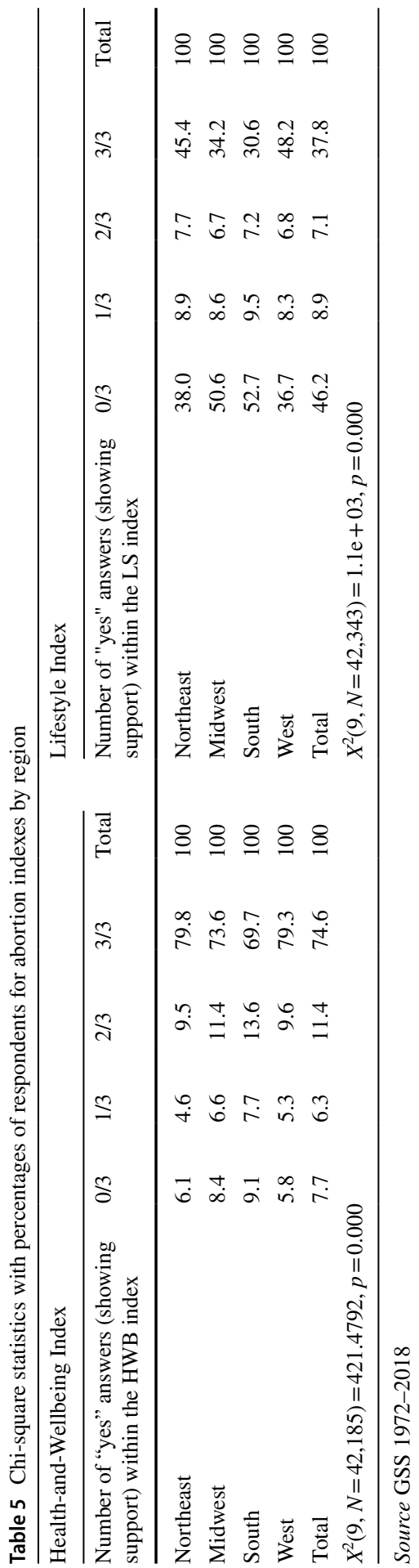




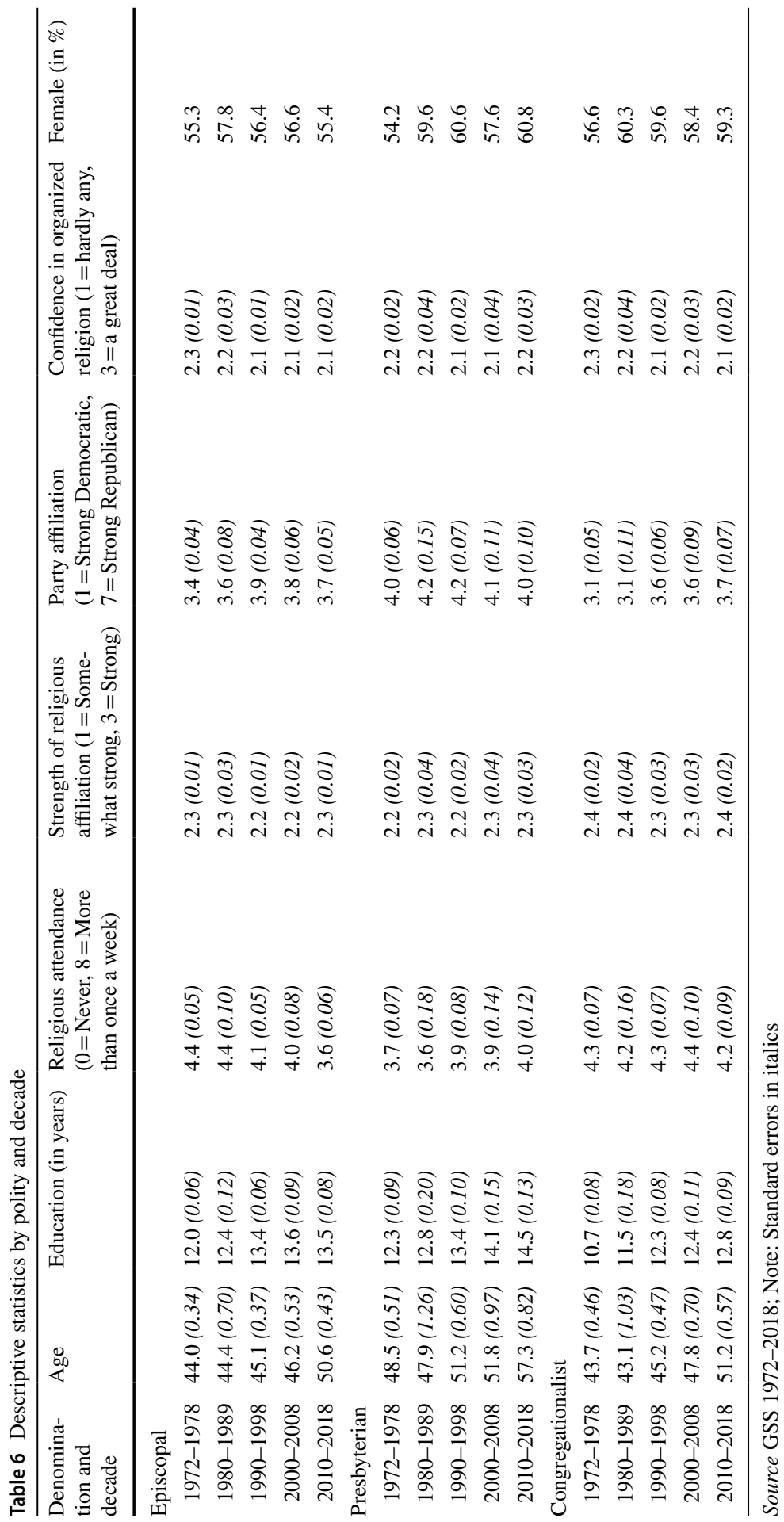



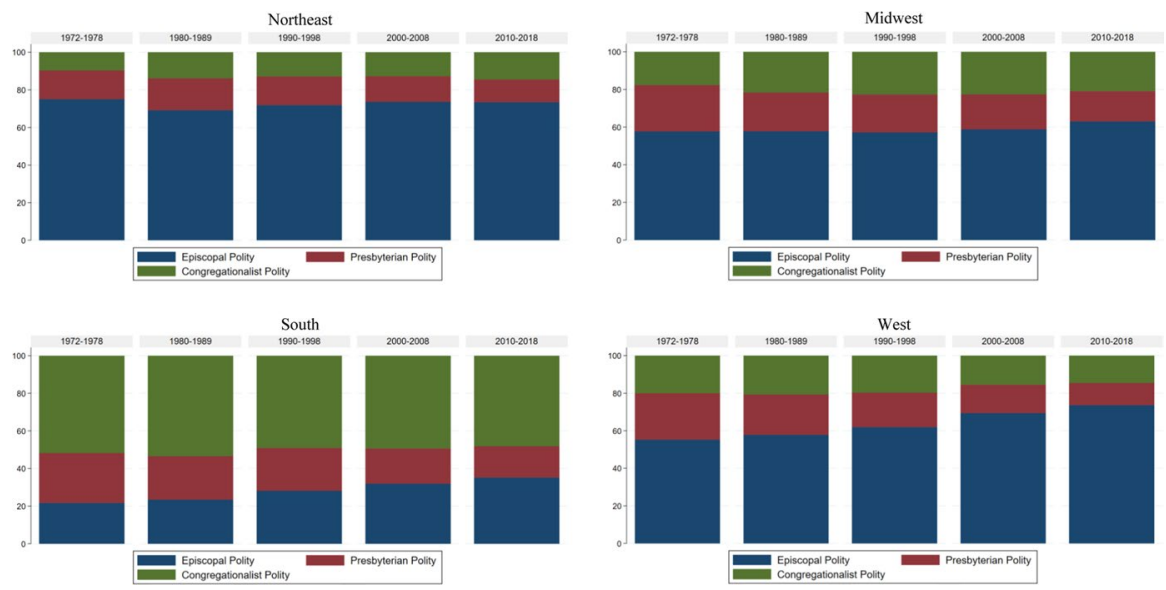

Fig. 1 Percentage of individuals affiliating with denominations within each religious polity by region and decade

those encompassed in this analysis. While the most obvious difference between the regions is the large percentage of individuals affiliating themselves with the denominations belonging to the Congregationalist polity in the South in comparison to the other regions that had substantial Episcopal polity denominational affiliation, the more nuanced changes within the regions are also of interest. In all four regions, the percentage of individuals affiliating with the Presbyterian polity denominations decreased in relation to the other polities, serving as the smallest polity in all regions by the 2010s. Concurrently, the Congregationalist polity saw slight growth in the Northeast and Midwest going into the 1980s, but this levelled out in the 1990s and the time thereafter. In the West and the South, however, the Congregationalists saw stable decreases after the 1990s and a slight increase going into the 1980s. In fact, the 1990s saw the first time that the Congregationalists no longer made up the majority of the affiliates in the South. These findings are in line with previous studies (Pew Research Center 2014). In particular, Warf and Winsberg (2008) found that the parts of the US that are predominantly Baptist and Catholic - or in the context of this paper, Congregationalist (Baptist) or Episcopal (Catholic) - are usually less religiously diverse than other regions, making sense in the context of this work with relation to the large percentages of either Episcopals (Northeast, Midwest, West) or Congregationalists (South).

Figure 2 denotes the averages of the HWB and LS indexes over the past five decades. Clearly the general opinion on abortion differs significantly with regards to the two indexes; however, very little difference is found between each polity. Across all graphs, support for LS abortions was around half that of HWB abortions. In the cases of HWB abortions, all polities averaged moderate support, showing similar results to the total survey population. Interpretatively, Fig. 2 highlights little variation across denominations and years, showing a level of stability in the midst of varied governmental and greater denominational responses. This, however, should be taken at face value due to the limiting nature of the descriptive statistics. 

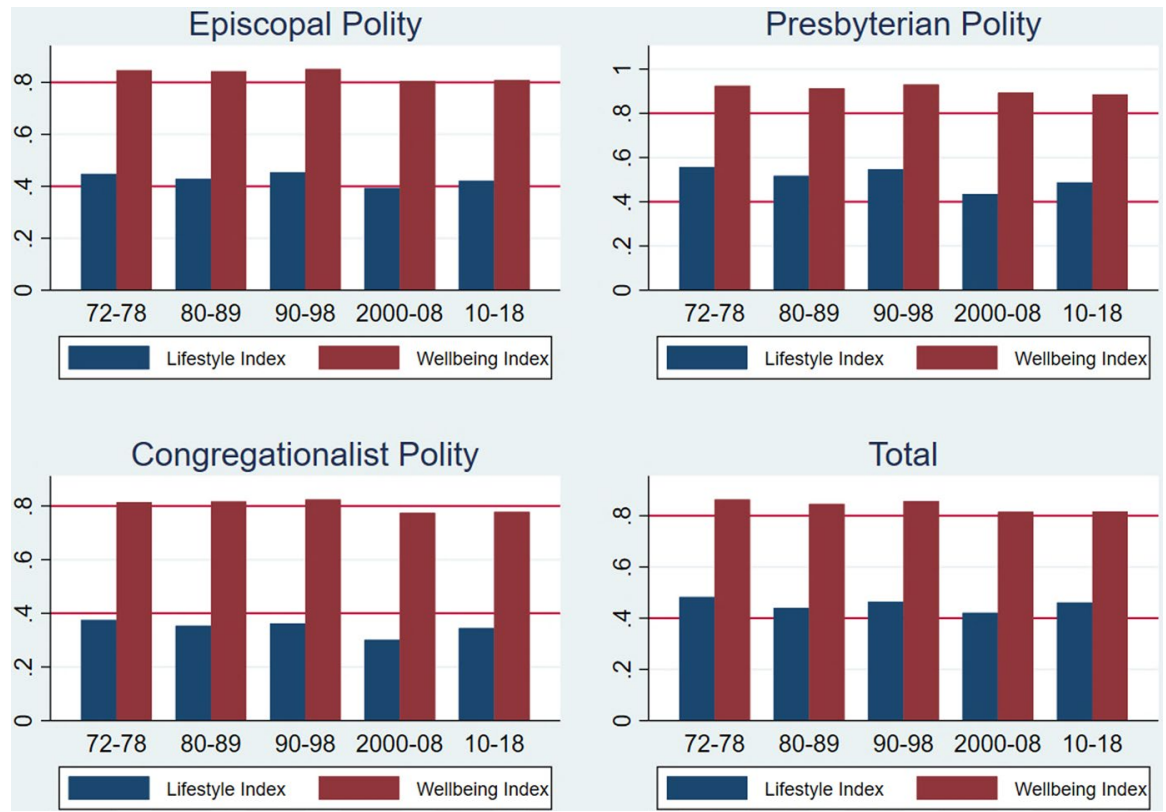

Fig. 2 Means for abortion indexes by polity and decade

Figures 3 and 4 build on this as they denote the responses of those affiliated to each denomination across the polities. Due to a number of these denominations having a small number of observations at some points of the survey, an average for each polity was added for better interpretation. Firstly, it is striking how similar the polities are overall when examining the LS and HWB indexes separately. In particular in Fig. 3, there is a level of stable support for HWB reasons for abortion over time. While the volatility of the individual denominations could warrant interest with more representative data, the striking finding here is that the polities had similar fluctuations.

Figure 4 highlights the responses to the LS index. Dissimilar to the HWB index, the average responses of the polities were more erratic, with shifting positions being more prevalent. This highlights the important factor of how controversial abortion really is when taken outside of the context of health-and-wellbeing risks. Since the debate surrounding lifestyle choices and abortion became heated throughout the 1970s and 1980s-particularly with the strengthening of the moralism debate - the variation found in responses is not surprising. It is important to note that even amidst this shifting climate, the overall change in support stayed relatively stable if not with a small decline, although the cross-sectional levels of support are still varying. That said, the Congregationalist polity showed the lowest levels of support for LS reasons for abortion, with the average being well under 0.5 across the entire timespan. The Episcopal and Presbyterian polities, however, showed a decent split in support across the timeframe. 

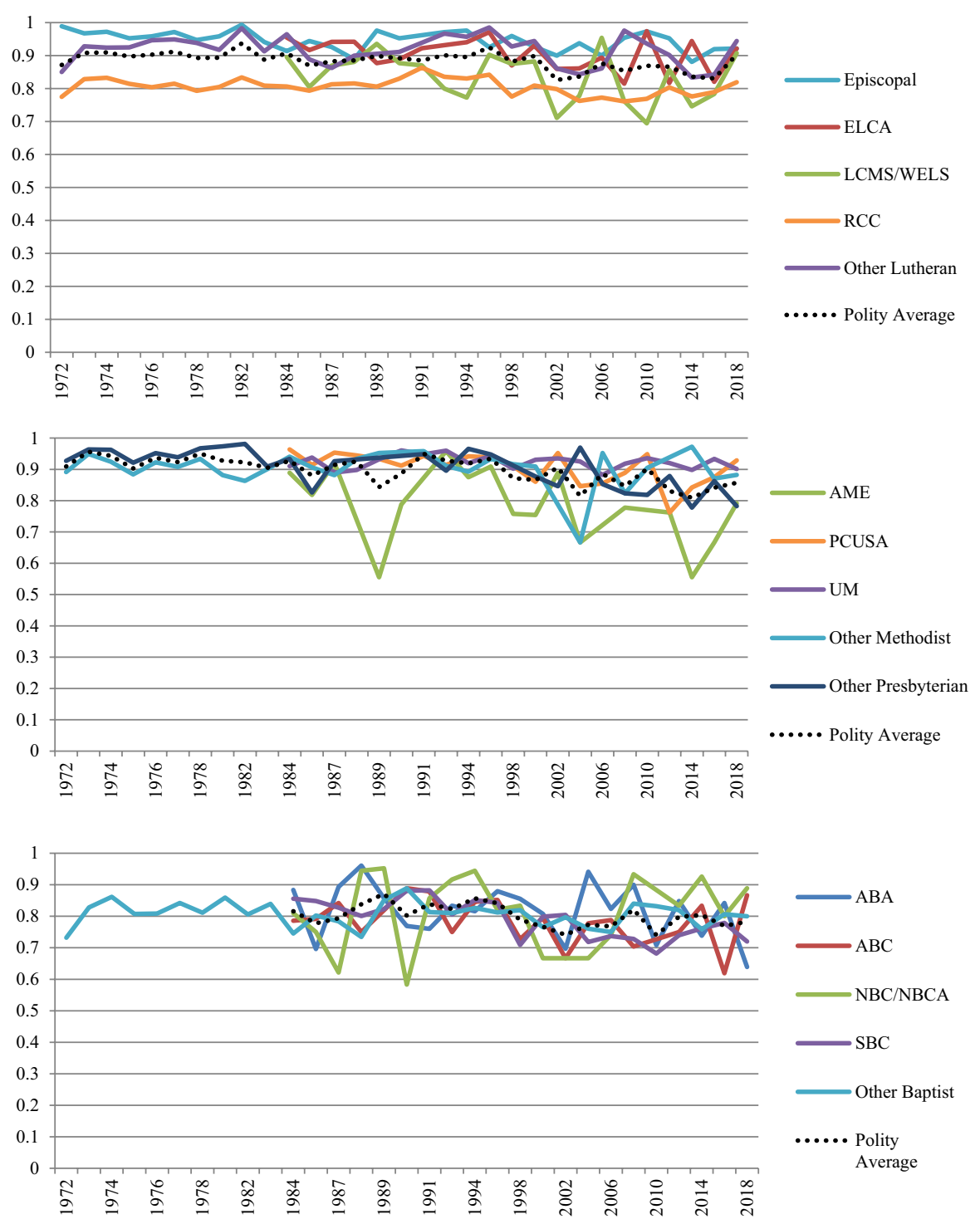

Fig. 3 Average HWB index score by year (denominations divided across polities: Episcopal, Presbyterian, Congregationalist)

\section{Results}

Tables 7 and 8 display the pooled OLS regressions with both indexes for abortion being investigated. For ease of interpretation, negative coefficients detail less support for abortions of the given index. Additionally, the dependent variables, the HWB and LS indexes, were coded on a scale from $0=$ no support to $1=$ full support. This means the smaller coefficients are due to the range of possible values for the 

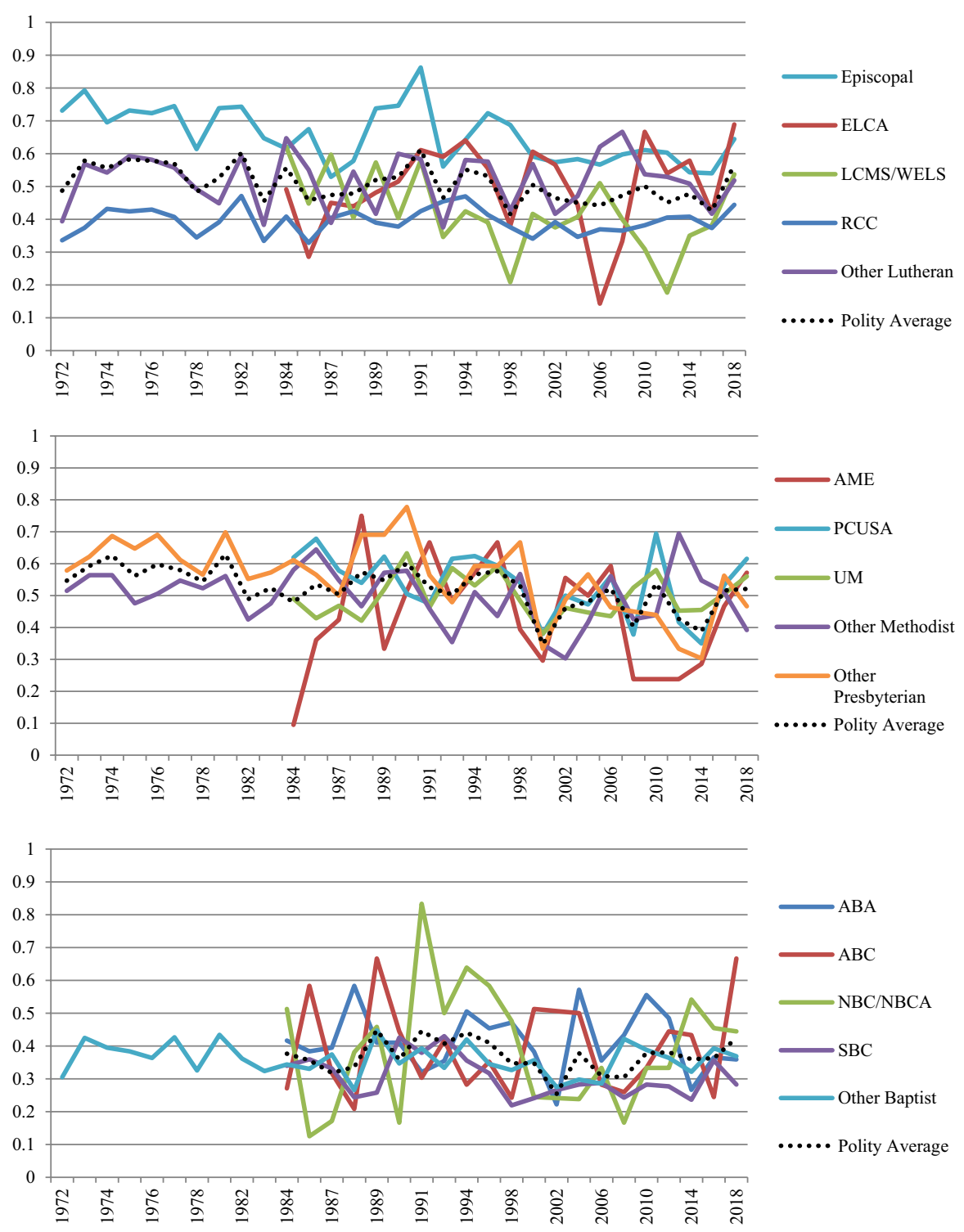

Fig. 4 Average LS index score by year (denominations divided across polities: Episcopal, Presbyterian, Congregationalist)

indexes falling between 0 and 1 . For Table 7, five models were run to test the effects of adding specific variables to model fit and other independent variables.

Model 1 illustrates the decade-effect coefficients with regard to the HWB index. Here, no significant effects were found for the 1980s or 1990s (with the 1970s serving as the base group). It is not until the 2000s where the effects become significant, with each decade for each polity showing a decrease in HWB support when 


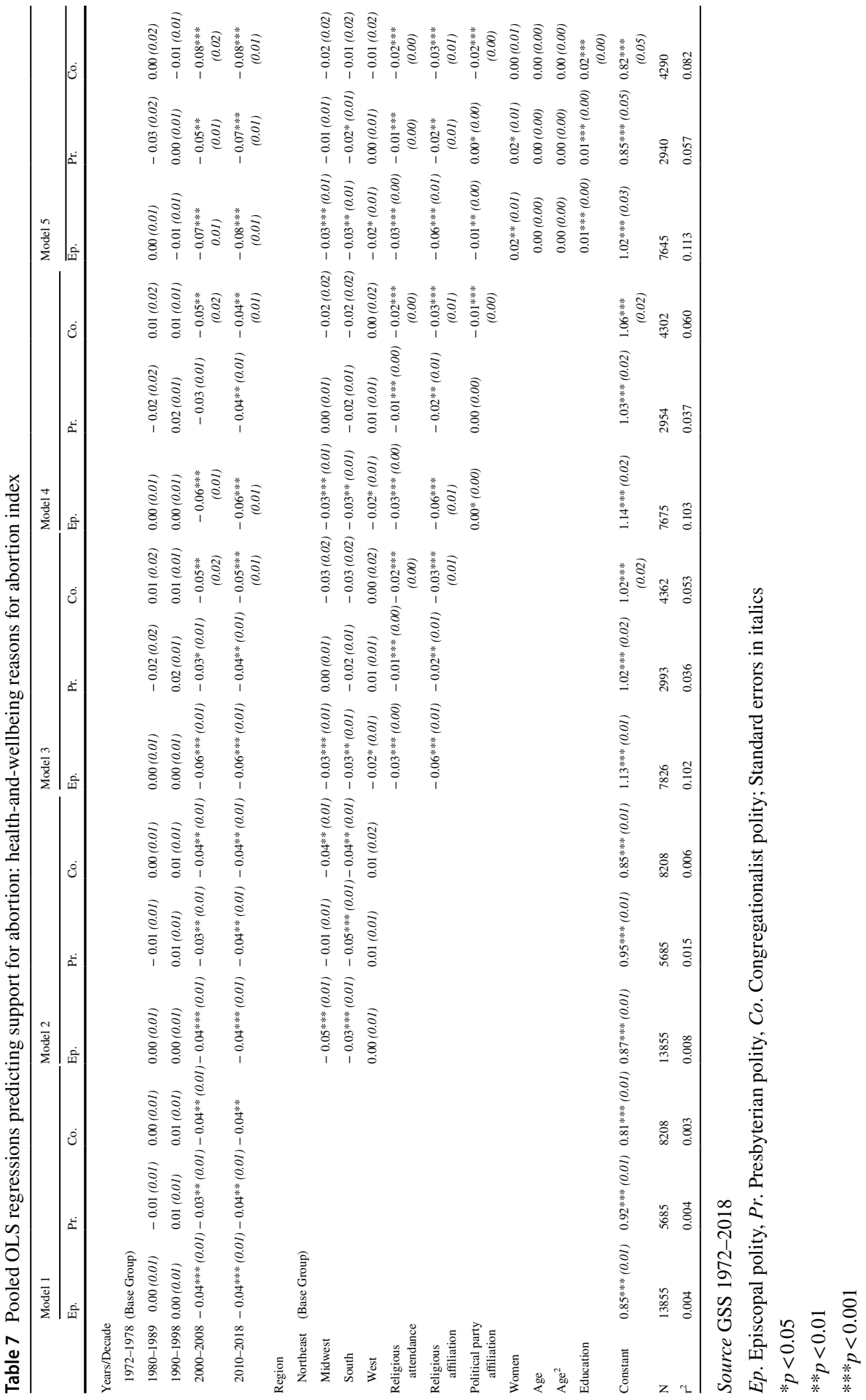


compared to the 1970s. The model fit was extremely low with only decade effects. In model 2, region effects were included with "Northeast" serving as the base group. Here, the Midwest and South regions both showed signs of having significantly lower HWB support than the Northeast, albeit with the Presbyterian polity not being significantly different in the Midwest. The West region, however, was not significantly different to the Northeast. The decade effects were not affected by the addition of this new variable, though the model fit did increase, albeit still being very weak. Model 3 included the two religious variables: religious attendance and strength of religious affiliation. Here, the inclusion of these variables greatly improved the model fit, particularly for the Episcopal polity. Furthermore, the strength of the decade effects increased in the 2000s and 2010s for the Episcopal and Congregationalist polities, while the region effects for the Presbyterian and Congregationalist polities became no longer significant. This means substantively that the effects of the religious variables served as mediators to explain the correlation that was witnessed in the regions from model 2. This makes sense in the light of regional differences in religious attendance and strengths of affiliation found in previous studies (Pew Research Center 2014). Furthermore, the inclusion of the religious variables actually strengthened the effects of the twenty-first century decades for the Episcopal and Congregationalist polities, meaning that when the religious variables are accounted for, the difference between the 1970s (the base group) and the later decades becomes ever so slightly more pronounced. Model 4 builds on this by adding the political party affiliation variable. Here, the correlation between political party affiliation and the HWB index, while menial, was still significant for each polity. Model fit was only noticeably improved for the Congregationalist polity. Finally, model 5 includes the rest of the control variables to produce the full model. Note here that the variable "confidence in organized religion" was not included when examining the HWB index as this variable was not found to be significantly correlated and was incredibly weak (see Table 4). Model fit was once again improved for all polities. With the inclusion of all variables, a few trends have formed. The twenty-first century appears to be much less supportive of HWB reasons for abortion than the 1970s, with every decade being negatively, and significantly, correlated. Regional effects seem to be most prevalent in the Episcopal polity, with all regions being significant and negatively correlated when compared to the base region, "Northeast." The religious variables were found to be significant and negatively correlated with HWB reasons for abortions, meaning that the strength of affiliation and amount of attendance both impacted the stances respondents held for every polity. This correlation was much stronger for the Episcopal and Congregationalist polities, though a weaker, still significant correlation was also found for the Presbyterian polity. While incredibly weak, the effect of political party affiliation was significant for the Episcopal and Congregationalist polities. However, there were no changes to any of the other variables with the inclusion of this variable; religious factors were still much stronger. Women were more supportive of HWB reasons for abortion in the Episcopal and Presbyterian polities than men, and higher education was correlated with more support for HWB reasons for abortion for every polity. Age had a menial, non-significant effect on stances for HWB abortions. As could be expected with such a small effect of age, the age squared variable had no notable effect. 


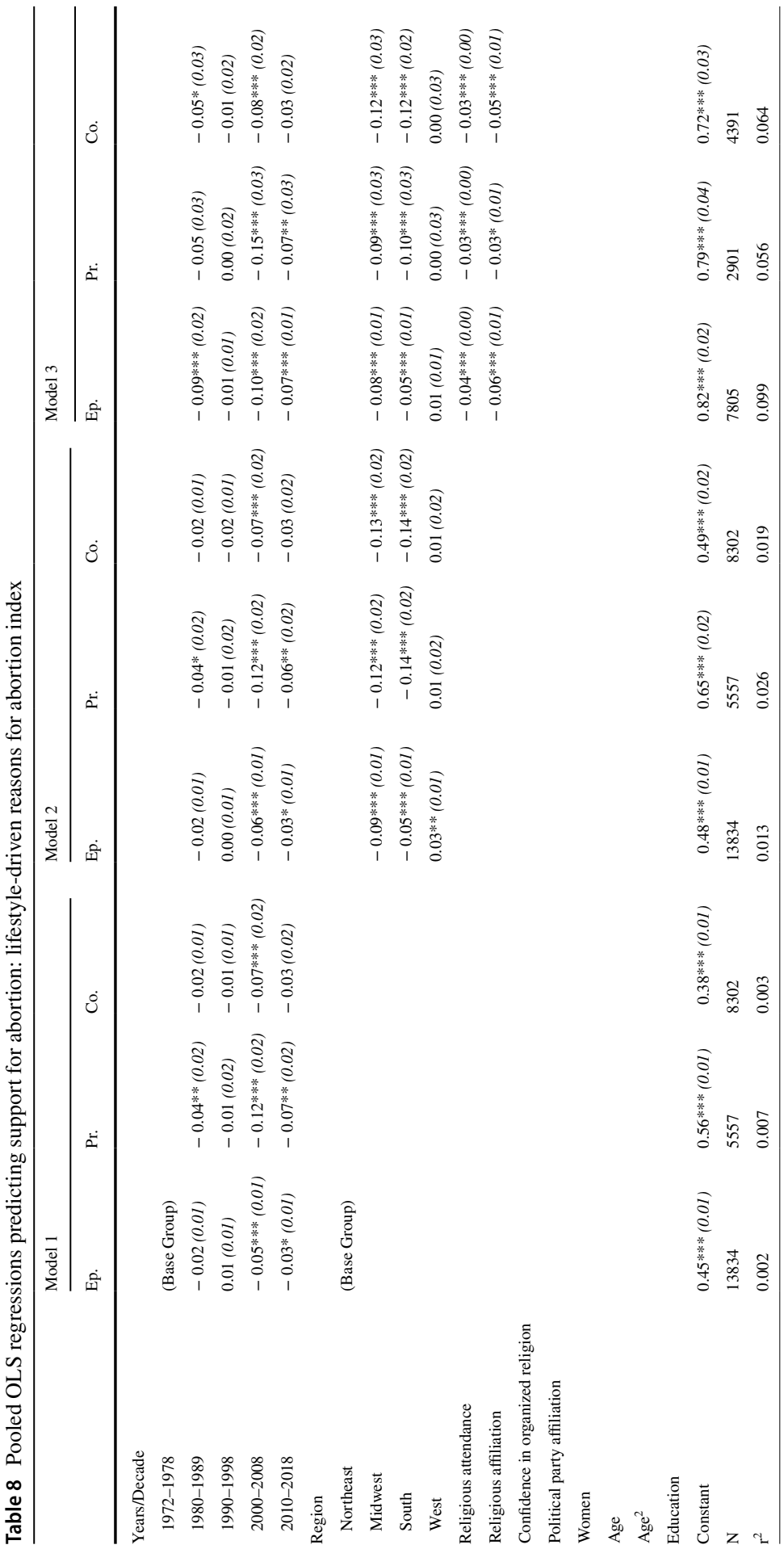

SN Social Sciences

A SPRINGER NATURE journal. 


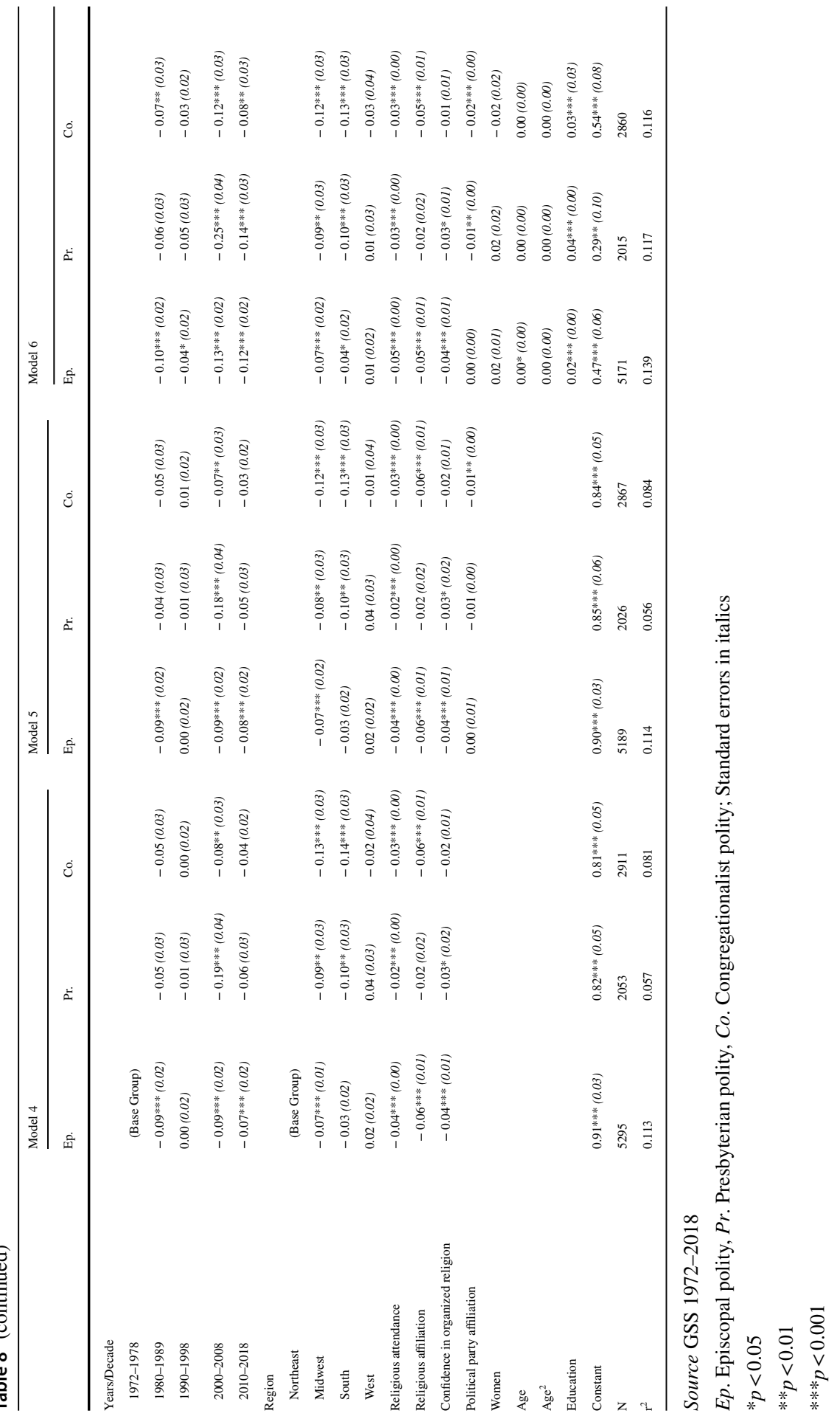

SN Social Sciences

A SPRINGER NATURE journal 
The same process was performed for the LS index as well; these results are seen in Table 8. In this table, a 6th model is presented due to the inclusion of the "confidence in organized religion" variable. In a similar case to the HWB index, the later decades show the strongest correlation with lower levels of support for LS reasons for abortion. One major difference is that the Presbyterian polity showed significance in the 1980s and had overall higher negative correlations than the case in Table 7. Similar to the HWB index, the model fit when using only decade effects is extremely low. With the introduction of the region variable, little changed for the decade effects. Here, the differences between the Northeast and both the Midwest and South are much stronger and significant, highlighting substantial regional differences in LS support that are irrespective of decade. The West, however, was only significantly different for the Episcopal polity, though it was quite weak. Once again, the region effects improved the model fit slightly. The inclusion of the religious variables in model 3 did weaken the coefficients for the Presbyterian polity, though this was accompanied by increases in differences between twenty-first century decades and the base 1970s. Furthermore, the Episcopal polity showed a significant and quite strong negative correlation between the 1980s and the LS index when compared to the base group. Religious attendance and strength of affiliation were both significantly correlated with lower support for LS reasons for abortion; however, the effects were similar to those found for the HWB index. Their inclusion also caused a massive spike in model fit for all polities, with the best model fit being found in the Episcopal polity.

The inclusion of the variable for confidence in organized religion in model 4 was significant and negative for the Episcopal and Presbyterian polities. It did, however, cause the regional effects to decrease and led to the Midwest becoming non-significant for the Episcopal polity; this was accompanied by an increase in model fit, which was also found in the Congregationalist polity. With the inclusion of political party affiliation in model 5 , we see once more that the effect is significant solely for the Congregationalist polity, though the size of the effect was negligible. It appears that for both the LS and the HWB indexes that when keeping an eye on religious factors, the role of political party affiliation does not exhibit strong correlations with individuals' views on abortion. This is furthered by the inclusion of political party affiliation having little effect on model fit.

With the inclusion of the final control variables in model 6, changes are found mostly with the decade effects, with only education showing a significant and positive correlation with support for LS reasons for abortion. With an eye on the decade effects, the strength of the coefficients increases across the board when compared to model 5. Furthermore, every decade becomes significant for the Episcopal polity and the 1980s also become significant for the Congregationalist polity, highlighting a trend of each decade showing signs of being more opposed to LS reasons for abortion than the 1970s. The 2000s also showed a stronger opposition to LS abortions than any other decade for all polities, perhaps in part owing to the upsurge of dialog over abortion and legislation that was passed in the 2000s that brought with it the focus of on the legality of issues such as "partial-birth" abortions and medical coverage of birth control. This rise encouraged these discussions to be salient not only in the political discourse, but in the language of faith and belief as well. 


\section{Discussion}

The results of these regressions show that there is a substantial amount of differences in what is behind the stances that individuals from the polities in question have on abortion. In particular, religious factors such as attendance rates and religious affiliation were important in forming views on abortion, correlating with more opposition to abortion in the case of both the LS and HWB indexes. However, these effects had varying strengths, with the Presbyterian polity seeing much more muted effects than the other polities. Interestingly, the denominations belonging to the Presbyterian polity were also quite active in making positional statements on abortion, which included stances on HWB abortions and how abortion should be regulated politically. With this in mind, the action of a denomination taking a stance on abortion while having an organizational structure that allows for more representation of its people seems not to have served as much of a role in shaping the views of the congregants. This is furthered by the strength and significance of the correlation between religious affiliation and attendance and both of the abortion indexes found in the other two polities.

As detailed in Fig. 2, all polities showed higher levels of support for abortion in cases of health-and-wellbeing concerns on average. With regard to the regression analyses, this is important to keep in mind as the correlation effects of decades, region, religious attendance, and education were all stronger for the LS index than they were for the HWB index. Even more interesting is the similar outcomes of the regressions across all polities and decades. While it was the case that, of the Presbyterian polity denominations, only the AME came out in full opposition to abortion, it is interesting to see that the decrease in support between the base group and the periods in the twenty-first century was the largest of all polities. This could also be evidence of a disconnect between the UMC and their initial statement made in 1972. While initially they came out in support of the legislation passed to allow abortion, this statement has been under scrutiny and constant redaction since 1976. These redactions show a consistent dissonance with the original statement for both the General Conferences and congregations. With a consistent shift toward a significant, more oppositional mindset, the statements made in the 2000s labeling abortion as an unacceptable method of birth control represent more closely the positions held by the laymen present in the GSS.

These findings do bring some doubt to the findings of Jelen (2009), who found that opinions on divisive social issues are grounded within religious and political affiliation. However, even while there are some significant correlations present here, it is by no means conclusive that these are the true causes of the formation of stances on abortion. Political party affiliation was also interesting as the effects were quite weak, symbolizing that the effects from religious factors and social factors were more important than political party affiliation in explaining differences in stances on abortion. This is also furthered by the fact that the inclusion of political party affiliation did not affect the coefficients from the religious variables, meaning that the effects of religious attendance and affiliation on the LS and HWB reasons for abortion were not in part explained by political party affiliation. 
In terms of social factors, the regions show striking differences from each other, with the Northeast and West being more supportive of LS reasons for abortion (shown as the West not being significantly different to the base group) and the South and Midwest being significantly less supportive of both LS and HWB abortions than the Northeast. There was some evidence that the Episcopal polity was significantly less supportive of HWB abortions than the Northeast, however, the effects for the regions in Table 7 are much weaker than those found in Table 8, highlighting the larger incongruence found between the denominations within polities and the polities themselves.

\section{Conclusion}

While it is clear that organizational structure is not the guiding factor that changes the viewpoints of congregants on abortion, the trends found within each of the polities and the disconnect of these trends to the overall positional statements of the denominations is striking. With these findings, a somewhat remarkable divide between the statements of the various denominations and the beliefs of the affiliated members seems to be present. While the discourse of such issues led legislators to create laws and regulations regarding the nature of when abortion would be acceptable and legal, the denominational responses thereto were toward the morality of the inevitable legislative decisions. These responses, however, were not always matching the beliefs of the majority of the denominational adherents, and in situations where real authority was shared with the congregations and laypeople, the positional statements either underwent major redactions, as was evidenced in the UMC, were guided by advocacy of a particular stance, or the divisive nature of the debate led denominations to make no declarative statement.

If the declarations given by the denominations do not inherently represent or alter the beliefs of the general congregation, then the stances of the denominations themselves are not usable in understanding the complex nature of individual belief. While religious affiliation showed a significant negative correlation with both HWB and LS reasons for abortion (except for the Presbyterian polity with the LS index), the weak correlation between political party affiliation and stances on abortion further leads to a question regarding to what extent affiliations truly shape stances on social issues. These findings lend themselves to the conclusions of Goren and Chapp (2017, pp. 123-125), where they held that people were likely to revise their affinities and religious orientations based on their stances on "culture war" issues, rather than changing their opinions to match that of their affiliated groups; which could be a factor in why the number of religiously affiliated has decreased steadily since the 1970s. As an extension, the actions taken to mobilize for specific social change, for instance with abortion, may not be due to religious bodies serving as a harbinger of shifting values. Perhaps, instead, research into these moments requires deeper insight into the social and political climates of the day as catalysts for social change and mobility.

As has been discussed amidst numerous denominations, there has been evidence of both decreasing religiosity and decreasing denominationalism in the US since the 
mid part of the twentieth century. Alongside this, the ongoing and virulent nature of the abortion debate in the US is one that has, since its onset, walked a close line with various religious traditions. With this discussion taking shape in the form of traditional family structures, life and death discussions, and moral impasses, many individuals have turned to religion to seek guidance in belief and acceptance. As such, the use of abortion as a measure for denominational structures of authority when dealing with social stimuli was ideal in assessing how denominations use their systems of authority to come to consensus on such divisive social issues.

Funding Open Access funding enabled and organized by Projekt DEAL through The German Research Foundation (DFG). No funding was received to assist with the preparation of this manuscript.

Data availability All data are available through the General Social Survey website: http://www.gss.norc. org/get-the-data.

Code availability Syntaxes for the article will be made available upon reasonable request.

\section{Declarations}

Conflict of interest The author states that there are no conflicts of interest to disclose.

Open Access This article is licensed under a Creative Commons Attribution 4.0 International License, which permits use, sharing, adaptation, distribution and reproduction in any medium or format, as long as you give appropriate credit to the original author(s) and the source, provide a link to the Creative Commons licence, and indicate if changes were made. The images or other third party material in this article are included in the article's Creative Commons licence, unless indicated otherwise in a credit line to the material. If material is not included in the article's Creative Commons licence and your intended use is not permitted by statutory regulation or exceeds the permitted use, you will need to obtain permission directly from the copyright holder. To view a copy of this licence, visit http://creativecommons.org/licen ses/by/4.0/.

\section{References}

Aghion P, Tirole J (1997) Formal and real authority in organizations. J Polit Econ 101(1):1-29. https:// doi.org/10.1086/262063

Archives of the Episcopal Church (1976-2000) The acts of convention. The episcopal church-general convention. https://episcopalarchives.org/cgi-bin/acts/acts_topic_search.pl?topic=Abortion. Accessed 7 July 2021

Ben Hafsa L (2015) Lobbying for the unborn: the American Catholic church and the abortion issue. Mémoire(s), Identité(s), Marg Dans Le Monde Occident Contemp. https://doi.org/10.4000/mimmoc. 2320

Bruce S (2002) God is dead: secularization in the west. Blackwell Publishing, Oxford

Bruce S (2011) Secularization: in defence of an unfashionable theory. Oxford University Press, Oxford

Chaves M (1993) Denominations as dual structures: an organizational analysis. Sociol Relig 54(2):147169. https://doi.org/10.2307/3712137

Congregation for the Doctrine of the Faith (1974) Declaration on procured abortion. http://www.vatican. va/roman_curia/congregations/cfaith/documents/rc_con_cfaith_doc_19741118_declaration-abort ion_en.html. Accessed 7 July 2021

Congregation for the Doctrine of the Faith (1987) Instruction on respect for human life in its origin and on the dignity of procreation replies to certain questions of the day. Roman Catholic Church 
Cox D, Jones RP (2017) America's changing religious identity. Public Religion Research Institute. https:// www.prri.org/research/american-religious-landscape-christian-religiously-unaffiliated/. Accessed 7 July 2021

Davie G (1990) Believing without Belonging: is this the future of religion in Britain? Soc Compass 37(4):455-469

Davie G (1996) Religion in Britain since 1945: believing without belonging. Oxford Blackwell Publishing, Oxford

Davis J, Bauman K (2013) School Enrollment in the United States: 2011. Population Characteristics. US Census Bureau

Djupe PA, Calfano BR (2013) Divine intervention? The influence of religious value communication on US. Intervention Policy Polit Behav 35:643-663. https://doi.org/10.1007/s11109-012-9211-3

Djupe PA, Friesen A (2018) Moralizing to the choir: the moral foundations of American clergy. Soc Sci Q 99(2):665-682. https://doi.org/10.1111/ssqu.12455

Djupe PA, Gilbert CP (2003) The prophetic pulpit: clergy, churches, and communities in American politics. Rowman \& Littlefield Publishers Inc, Oxford

Evangelical Lutheran Church in America (1991) A social statement on: abortion. Evangelical Lutheran Church in America Churchwide Assembly. Meeting in Orlando, Florida on 28 Auguest-04 September 1991

Falwell J (1987) Strength for the journey. Simon \& Schuster, New York

Finke R, Stark R (2005) The churching of America, 1776-2005: winners and losers in our religious economy, 2nd edn. Rutgers University Press, New Brunswick

General Board of American Baptist Churches in the USA (2002) American Baptist resolution concerning abortion and ministry in the local church. Resolution 8006.5:12/87

Gibson T (2008) Religion and civic engagement among America's youth. Soc Sci J 45(3):504-514. https://doi.org/10.1016/j.soscij.2008.07.007

Goren P, Chapp C (2017) Moral power: how public opinion on culture war issues shapes partisan predispositions and religious orientations. Am Polit Sci Rev 111(1):110-128. https://doi.org/10.1017/ S0003055416000435

Graham J, Haidt J (2010) Beyond beliefs: religions bind individuals into moral communities. Pers Soc Psychol Rev 14(1):140-150. https://doi.org/10.1177/1088868309353415

Guth JL, Smidt CE (2019) Protestant Clergy in the 2016 Presidential Election. Conference Paper: Annual Meeting of the Southern Political Science Association, Austin, TX, January 2019

Hanson G, Xiang C (2013) Exporting Christianity: governance and doctrine in the globalization of US denominations. J Int Econ 91(2):301-320. https://doi.org/10.1016/j.jinteco.2013.08.002

Hoffmann JP, Johnson SM (2005) Attitudes toward abortion among religious traditions in the United States: change or continuity? United States: change or continuity? Sociol Relig 66(2):161-182. https://doi.org/10.2307/4153084

Hofman BD (1986) Political theology: the role of organized religion in the anti-abortion movement. J Church State 28:225-247

Hoge D, Johnson B, Luidens D (1993) Determinants of church involvement of young adults who grew up in Presbyterian churches. J Sci Stud Relig 32(1):242-255. https://doi.org/10.2307/1386663

Horowitz J (2019) Pope Francis says abortion, even of a sick fetus, is like hiring a "Hitman," The New York Times (May 25). https://www.nytimes.com/2019/05/25/world/europe/pope-abortion-sickfetus.html. Accessed 7 July 2021

Hout M, Fischer CS (2002) Why more Americans have no religious preference: politics and generations. Am Sociol Rev 67(2):165-190. https://doi.org/10.2307/3088891

Hunter JD, Davis JE (1995) Cultural politics at the edge of life. J Policy Hist 7(1):103-127. https://doi. org/10.1017/S0898030600004164

Iannaccone LR (2012) Extremism and the economics of religion. Econ Rec 88(SUPPL1):110-115. https://doi.org/10.1111/j.1475-4932.2012.00803.x

Iannaccone LR, Finke R, Stark R (1997) Deregulating religion: the economics of church and state. Econ Inq 35(2):350-364. https://doi.org/10.1111/j.1465-7295.1997.tb01915.x

Jelen T (2009) Religion and American public opinion: social issues. In: Schmidt C, Kellstedt L, Guth J (eds) The Oxford handbook of religion and American politics. Oxford University Press, New York, pp 217-242

Lewis AR (2014) Abortion politics and the decline of the separation of church and state: the Southern Baptist case. Pol Relig 7:521-549. https://doi.org/10.1017/S1755048314000492 
Lewis AR, De Bernardo DH (2010) Belonging without belonging: utilizing evangelical self-identification to analyze political attitude and preferences. J Sci Stud Relig 49(1):112-126. https://doi.org/10. 1111/j.1468-5906.2009.01495.x

Lipka M (2016) Are churches key to solving social problems? Fewer Americans now think so. Pew Research Center. https://www.pewresearch.org/fact-tank/2016/07/18/are-churches-key-to-solvingsocial-problems-fewer-americans-now-think-so/. Accessed 7 July 2021

Malka A, Soto CJ (2011) The conflicting influences of religiosity on attitude toward torture. Pers Soc Psychol Bull 37(8):1091-1103. https://doi.org/10.1177/0146167211406508

Malka A, Lelkes Y, Srivastava S, Cohen AB, Miller DT (2012) The association of religiosity and political conservatism: the role of political engagement. Pol Psychol 22(3):275-299. https://doi.org/10. 1111/j.1467-9221.2012.00875x

Margolis MF (2018) How politics affects religion: partisanship, socialization, and religiosity in America. J Polit 80(1):30-43. https://doi.org/10.1086/694688

Masci D (2016) Where major religious groups stand on abortion. Pew Research Center. https://www. pewresearch.org/fact-tank/2016/06/21/where-major-religious-groups-stand-on-abortion/. Accessed 7 July 2021

McKeegan M (1993) The politics of abortion: a historical perspective. Women's Health Issues 3(3):127131. https://doi.org/10.1016/s1049-3867(05)80245-2

Mueller O (2009) Religiosity in Central and Eastern Europe: results from the PCE 2000 survey in comparison. In: Pickel G, Mueller O (eds) Church and religion in contemporary Europe. VS Verl für Sozialwiss, Wiesbaden, pp 65-88

Mylchreest I (1995) "Sound law and undoubtedly good policy": Roe v. wade in comparative perspective. J Pol Hist 7(1):53-71. https://doi.org/10.1017/S0898030600004140

National Abortion Rights Action League (2021) Abortion access. National abortion rights action league. https://www.prochoiceamerica.org/issue/abortion-access/. Accessed 7 July 2021

National Right to Life (2021) National right to life mission statement. National Right to Life. https:// www.nrlc.org/about/mission/. Accessed 7 July 2021

Newport F (2015) Percentage of Christians in US. Drifting down, but still high. Gallup. https://news.gallup.com/poll/187955/percentage-christians-drifting-down-high.aspx. Accessed 7 July 2021

Newport F (2017) 2017 Update on Americans and religion. Gallup. https://news.gallup.com/poll/224642/ 2017-update-americans-religion.aspx. Accessed 7 July 2021

Norris P, Inglehart R (2004) Sacred and secular. Cambridge University Press, Cambridge

Office of the General Assembly (1970) Minutes of the General Assembly of the United Presbyterian Church in the United States of America. United Presbyterian Church in the USA. General Assembly

Pew Research Center (2014) Religious landscape study: views about abortion. Pew research center. https://www.pewforum.org/religious-landscape-study/views-about-abortion/. Accessed 7 July 2021

"Planned Parenthood of Southeastern Pennsylvania v. Casey" (1992) Oyez. www.oyez.org/cases/1991/ 91-744. Accessed 7 July 2021

Pollack D (2015) Varieties of secularization theories and their indispensable core. German Rev 90(1):6079. https://doi.org/10.1080/00168890.2015.1002361

Pollack D (2009) Rückkehr Des Religiösen? Mohr Siebeck, Tübingen

Pope John Paul II (1995) Evangelium vitae. Papal encyclicals online. http://w2.vatican.va/content/johnpaul-ii/en/encyclicals/documents/hf_jp-ii_enc_25031995_evangelium-vitae.html. Accessed 7 July 2021

Pope Paul VI (1968) Humanae Vitae. Papal encyclicals online. http://w2.vatican.va/content/paul-vi/en/ encyclicals/documents/hf_p-vi_enc_25071968_humanae-vitae.html. Accessed 7 July 2021

Pope Pius XI (1930) Casti Connubii: on Christian marriage. Papal encyclicals online. http://www.papal encyclicals.net/pius11/p11casti.htm. Accessed 7 July 2021

Presbyterian Mission (2016) Abortion/reproductive choice issues. Presbyterian Church (USA). Presbyterian mission. https://www.presbyterianmission.org/blog/abortion-issues-2/. Accessed 7 July 2021

Reed JW (1995) The birth-control movement before roe v. Wade J Pol Hist 7(1):22-52. https://doi.org/10. 1017/S0898030600004139

Sharpless J (1995) World population growth, family planning, and American foreign policy. J Pol Hist 7(1):72-102. https://doi.org/10.1017/S0898030600004152

Shelton RL (1997) Biomedical ethics in methodist traditions. Bioethics Yearbook 5(1):189-220. https:// doi.org/10.1007/978-94-017-0904-0_10 
Sherkat DE, Powell-Williams M, Maddox G, de Vries KM (2011) Religion, politics, and support for same-sex marriage in the United States, 1988-2008. Soc Sci Res 40(1):167-180. https://doi.org/10. 1016/j.ssresearch.2010.08.009

Smidt CE (2016) Pastors and public life: the changing face of American protestant clergy. Oxford University Press, Oxford

Smith TW, Marsden P, Hout M, Kim J (2019) General social surveys, 1972-2018 http://www.gss.norc. org/get-the-data. Accessed 7 July 2021

Social Concerns Committee (1984) Abortion in perspective: a report of the commission on theology and church relations of the Lutheran church- Missouri synod. The Lutheran Church-Missouri synod. https://www.lcms.org/about/leadership/commission-on-theology-and-church-relations/documents/ life-issues. Accessed 7 July 2021

Southern Baptist Convention (1971) Resolution on abortion. https://www.sbc.net/resource-library/resol utions/resolution-on-abortion-2/. Accessed 7 July 2021

Southern Baptist Convention (1980) Resolution on abortion. https://www.sbc.net/resource-library/resol utions/resolution-on-abortion-6/. Accessed 7 July 2021

Southern Baptist Convention (2015) On the sanctity of human life. https://www.sbc.net/resource-library/ resolutions/on-the-sanctity-of-human-life/. Accessed 7 July 2021

Taylor M, Merino S (2011) Race, religion, and beliefs about racial inequality. Ann Am Acad Pol Soc Sci 634(1):60-77. https://doi.org/10.1177/0002716210389537

Uecker JE, Regnerus MD, Vaaler ML (2007) Losing my religion: the social sources of religious decline in early adulthood. Soc Forces 85(4):1667-1692. https://doi.org/10.1353/sof.2007.0083

United Methodist Church (2016) The book of discipline of the United Methodist church-2016. The United Methodist Publishing House, Nashville

Voas D, Chaves M (2016) Is the United States a counterexample to the secularization thesis? Am J Sociol 121(5):1517-1556. https://doi.org/10.1086/684202

Warf B, Winsberg M (2008) The geography of religious diversity in the United States. Prof Geogr 60(3):413-424. https://doi.org/10.1080/00330120802046786

Williams DK (2011) The GOP's abortion strategy: why pro-choice republicans became pro-life in the 1970s. The J Pol Hist 23(4):513-539. https://doi.org/10.1017/S0898030611000285

Williams DK (2015) The partisan trajectory of the American pro-life movement: how a liberal catholic campaign became a conservative evangelical cause. Religions 6:451-475. https://doi.org/10.3390/ rel6020451

Wisconsin Evangelical Lutheran Synod (2011) Abortion. What we believe/doctrinal statements. https:// wels.net/about-wels/what-we-believe/doctrinal-statements/abortion/. Accessed 7 July 2021 